Article

\title{
Chemical and Pharmacological Screening of Rhinella icterica (Spix 1824) Toad Parotoid Secretion in Avian Preparations
}

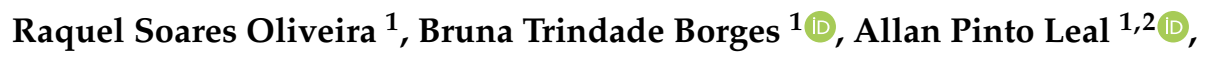 \\ Manuela Merlin Lailowski ${ }^{3}$, Karla de Castro Figueiredo Bordon ${ }^{4}{ }^{\oplus}$, Velci Queiróz de Souza ${ }^{1}$, \\ Lúcia Vinadé $^{1, *(\mathbb{D})}$, Tiago Gomes dos Santos ${ }^{5} \mathbb{D}$, Stephen Hyslop ${ }^{6}$, Sidnei Moura ${ }^{3}$, \\ Eliane Candiani Arantes ${ }^{4}\left(\mathbb{D}\right.$, Alexandre Pinto Corrado ${ }^{7}$ and Cháriston A. Dal Belo ${ }^{1,2, * \mathbb{D}}$ \\ 1 Laboratório de Neurobiologia e Toxinologia, Programa de Pós-Graduação em Ciências Biológicas (PPGCB), \\ Universidade Federal do Pampa (UNIPAMPA), Avenida Antônio Trilha 1847, \\ São Gabriel RS 97300-000, Brazil; raquelsoaresoliveira@yahoo.com.br (R.S.O.); \\ brunaborges@alunos.unipampa.edu.br (B.T.B.); allan-leal@hotmail.com (A.P.L.); \\ velcisouza@unipampa.edu.br (V.Q.d.S.) \\ 2 Programa de Pós-Graduação em Ciências Biológicas: Bioquímica Toxicológica (PPGBTox), \\ Universidade Federal de Santa Maria (UFSM), Avenida Roraima 1000, Santa Maria RS 97105-900, Brazil \\ 3 Laboratório de Biotecnologia de Produtos Naturais e Sintéticos, Instituto de Biotecnologia, Universidade de \\ Caxias do Sul (UCS), Rua Francisco Getúlio Vargas 1130, Caxias do Sul RS 95070-560, Brazil; \\ manusnowwhite@yahoo.com.br (M.M.L.); smsilva11@ucs.br (S.M.) \\ 4 Departamento de Ciências BioMoleculares, Faculdade de Ciências Farmacêuticas de Ribeirão Preto, \\ Universidade de São Paulo (USP), Avenida do Café, s/n, Ribeirão Preto SP 14.040-903, Brazil; \\ karla@fcfrp.usp.br (K.d.C.F.B.); ecabraga@fcfrp.usp.br (E.C.A.) \\ 5 Laboratório de Estudos em Biodiversidade Pampiana, Universidade Federal do Pampa (UNIPAMPA), \\ Avenida Antônio Trilha 1847, São Gabriel RS 97300-000, Brazil; frogomes@gmail.com \\ 6 Departamento de Farmacologia, Faculdade de Ciências Médicas, Universidade Estadual de \\ Campinas (UNICAMP), Rua Tessália Vieira de Camargo, 126, Cidade Universitária Zeferino Vaz, \\ Campinas SP 13083-887, Brazil; hyslop@unicamp.br \\ 7 Departamento de Farmacologia, Faculdade de Medicina de Ribeirão Preto, Universidade de São \\ Paulo (USP), Avenida Bandeirantes 3900, Ribeirão Preto SP 14040-030, Brazil; apcorrad@fmrp.usp.br \\ * Correspondence: luciavinade@unipampa.edu.br (L.V.); charistonbelo@unipampa.edu.br (C.A.D.B.); \\ Tel.: +55-55-3237-0850 (C.A.D.B.)
}

Received: 23 April 2020; Accepted: 22 May 2020; Published: 15 June 2020

\begin{abstract}
The biological activity of Rhinella icterica parotoid secretion (RIPS) and some of its chromatographic fractions (RI18, RI19, RI23, and RI24) was evaluated in the current study. Mass spectrometry of these fractions indicated the presence of sarmentogenin, argentinogenin, $(5 \beta, 12 \beta)-2,14$-dihydroxy-11-oxobufa-3,20,22-trienolide, marinobufagin, bufogenin B, 11 $\alpha, 19$-dihydroxytelocinobufagin, bufotalin, monohydroxylbufotalin, 19-oxo-cinobufagin, $3 \alpha, 12 \beta, 25,26$-tetrahydroxy7-oxo-5 $\beta$-cholestane-26-O-sulfate, and cinobufagin-3-hemisuberate that were identified as alkaloid and steroid compounds, in addition to marinoic acid and $N$-methyl-5-hydroxy-tryptamine. In chick brain slices, all fractions caused a slight decrease in cell viability, as also seen with the highest concentration of RIPS tested. In chick biventer cervicis neuromuscular preparations, RIPS and all four fractions significantly inhibited junctional acetylcholinesterase (AChE) activity. In this preparation, only fraction RI23 completely mimicked the pharmacological profile of RIPS, which included a transient facilitation in the amplitude of muscle twitches followed by progressive and complete neuromuscular blockade. Mass spectrometric analysis showed that RI23 consisted predominantly of bufogenins, a class of steroidal compounds known for their cardiotonic activity mediated by a digoxin- or ouabain-like action and the blockade of voltage-dependent L-type calcium channels. These findings indicate that the pharmacological activities of RI23 (and RIPS) are probably mediated by:
\end{abstract}


(1) inhibition of AChE activity that increases the junctional content of Ach; (2) inhibition of neuronal $\mathrm{Na}^{+} / \mathrm{K}^{+}$-ATPase, leading to facilitation followed by neuromuscular blockade; and (3) blockade of voltage-dependent $\mathrm{Ca}^{2+}$ channels, leading to stabilization of the motor endplate membrane.

Keywords: Anti-AChE activity; avian; chick neurobiological preparations; cytotoxicity; neuromuscular blockade; toad poison

Key Contribution: This work provides new information on the chemical composition and biological activity of parotoid secretion of the toad Rhinella icterica, particularly in relation to possible interaction with $\mathrm{AChE}$, the $\mathrm{Na}^{+} / \mathrm{K}^{+}$-ATPase pump, and $\mathrm{Ca}^{2+}$ channels.

\section{Introduction}

Brazil is the country with the richest biodiversity of anuran amphibians, with 1093 catalogued species, of which at least 42 are on the list of endangered species [1-3]. Of particular interest are the biological activities of anuran gland and skin secretions, not only because of their physiological, behavioral, and ecological functions, but also because their complex composition provides a rich source of novel chemicals with potential biotechnological and therapeutic applications [4-8]. In addition, many anurans (and amphibians in general) have complex mechanisms to avoid diseases, parasites, and predation that frequently involve the use of a variety of secretions, the composition of which may be modulated by environmental factors [9-11].

Toads possess cutaneous glands that are broadly classified into two types: mucous glands, that produce mucus involved in cutaneous respiration, thermoregulation, and reproduction; and granular glands, that secrete noxious or toxic compounds used as a defense against predators [12-14]. These secretions consist mainly of alkaloids, steroids (bufadienolides and bufotoxins), biogenic amines (epinephrine, norepinephrine, serotonin, bufotenine, and dehydrobufotenine), proteins, and peptides $[6,12,13,15]$, and act by direct contact with the mucous membranes of the mouth, eye, or throat of potential predators $[9,16]$.

In traditional Chinese, Indian, and Egyptian medicine, cardiotonic steroids from plants, animals, or minerals have been widely used for millennia to treat sores, heart failure, pain, and different types of cancer [17-20]. For therapeutic applications, the most important amphibian secretions are obtained from toads of the family Bufonidae [6,21] and have been widely used in America, Asia, and Europe as antiviral agents (to treat human immunodeficiency virus (HIV)), as well as for their anti-proliferative [22-24], antibacterial [25], antiparasitic [26], insecticidal [27,28], antidiabetic [29], anti-cancer [30,31], anti-inflammatory, and analgesic [7,32-34] activities. Many compounds that occur in toad secretions, e.g., bufalin, telocinobufagin, hellebrin, marinobufagin, and cinobufagin, can vary markedly among individuals, geographic regions, and species in response to environmental conditions, e.g., temperature, and dietary composition, and may involve morphological adaptations [14,35,36].

Rhinella icterica (Spix, 1824), the "yellow cururu toad", is a large anuran of the family Bufonidae that is native to South America and occurs in Brazil, Paraguay, and Argentina [3,37]. Rhinella icterica parotoid secretion (RIPS) has antimicrobial activity against Escherichia coli and Staphylococcus aureus [38]. In a previous report, we showed that RIPS was toxic to the peripheral and central nervous systems of avian, mammalian, and insect species through a digitalis-like action [27,39]. Although preliminary studies of RIPS have identified some chemical components, such as dehydrobufotenine, hellebrigenin, telocinobufagin, marinobufagin, bufotalin, bufalin, and 19-oxo-cinobufagin [13,36,39], no previous study has sought to examine the chemical constitution of this secretion in detail and to assess its specific interaction with the avian nervous system. In this work, we investigated the chemical composition of RIPS to identify the main groups of compounds responsible for the acute neurotoxicity caused by this secretion at avian skeletal neuromuscular junctions. 
Based on pharmacological screening in tissue slices and avian neuromuscular preparations, the most important finding of this work was that the two main neurotoxic effects (muscle twitch-tension facilitation and neuromuscular blockade) observed in Rhinella icterica fraction 23 (RI23) could be dissociated; this observation suggested the presence of at least two different molecules responsible for the overall toxicity of the secretion. The action of RI23 at the avian neuromuscular junction was complex and involved an increase in acetylcholine (ACh) release via an ouabain-like mechanism combined with anti-acetylcholinesterase (anti-AChE) activity and a membrane-stabilizing activity similar to propranolol.

\section{Results}

\subsection{Biochemical Characterization of RIPS by FPLC}

Fractionation of RIPS ( $5 \mathrm{~mL}$ of a $2 \mathrm{mg} / \mathrm{mL}$ solution) by reversed-phase fast protein liquid chromatography (RP-FPLC) on a C18 column resulted in 30 fractions (Figure 1a), all of which were initially screened for neuromuscular activity in chick biventer cervicis preparations. Only fractions 18 , 19,23 , and 24 showed neuromuscular activity and these were therefore chosen for further investigation. The electrophoretic profile of RIPS showed the presence of proteins ranging from $\sim 10 \mathrm{kDa}$ to $200 \mathrm{kDa}$, with the main components around $45 \mathrm{kDa}, 97 \mathrm{kDa}$, and $200 \mathrm{kDa}$ (Figure 1b). Fractions RI18, RI19, RI23, and RI24 showed no proteins below $200 \mathrm{kDa}$.

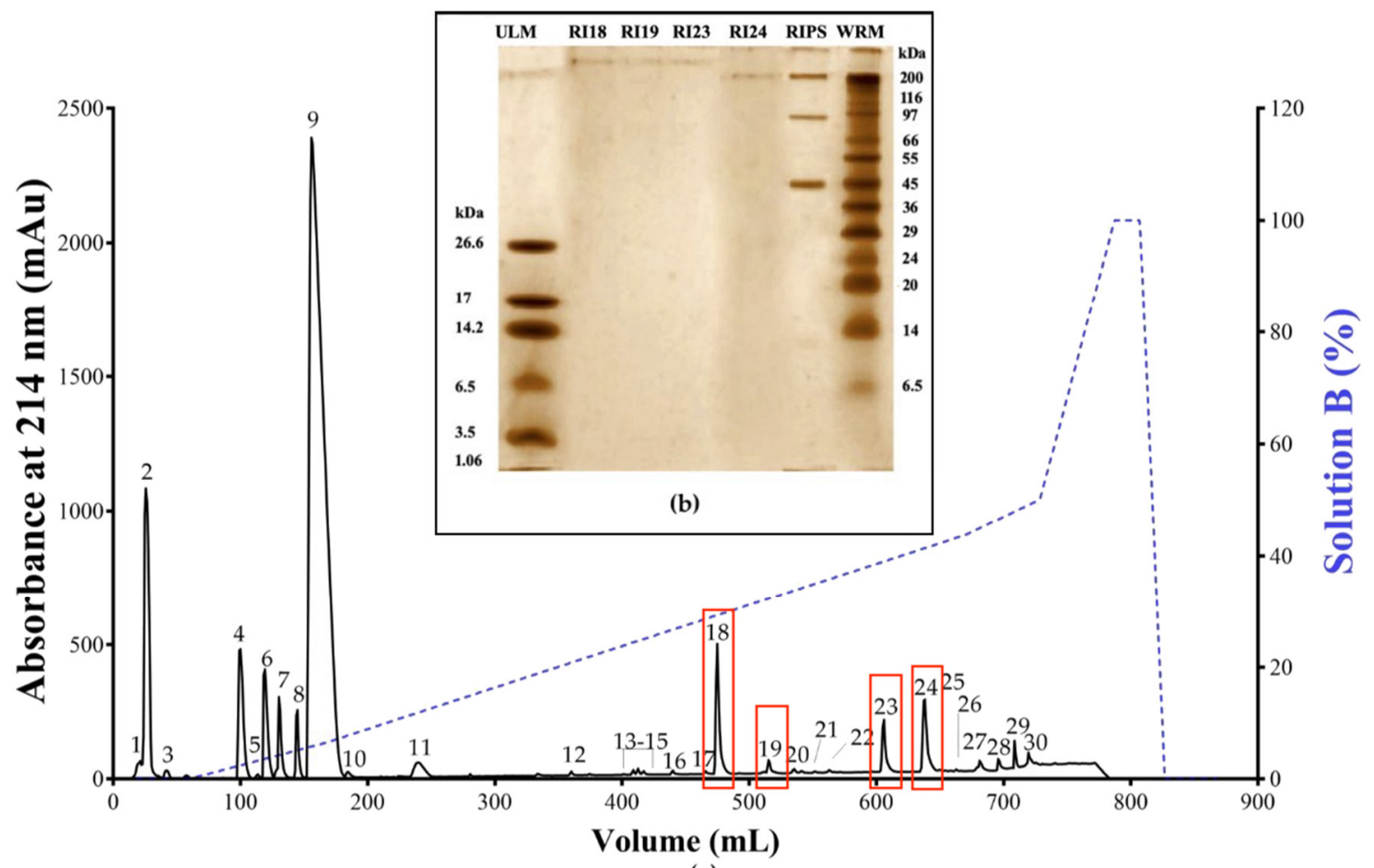

(a)

Figure 1. (a) Reversed-phase fast protein liquid chromatography (RP-FPLC) elution profile of R. icterica parotoid secretion (RIPS) and (b) Tricine-sodium dodecyl sulfate-polyacrylamide gel electrophoresis (SDS-PAGE) profile of fractions RI18, RI19, RI23, and RI24. RIPS (10 mg) was applied to a C18 column pre-equilibrated with $0.1 \%$ trifluoroacetic acid (TFA). The secretion components were then eluted $(1 \mathrm{~mL} / \mathrm{min})$ with a two-step gradient of solution B $(60 \%$ acetonitrile in $0.1 \%$ TFA $)$ and the elution profile was monitored at $214 \mathrm{~nm}$ (solid line); the dotted line shows the gradient of solution B. Panel (b) shows the Tricine-SDS-PAGE profile of fractions RI18, RI19, RI23, and RI24 (2 $\mu$ g each) in a 16.5\% polyacrylamide gel stained with silver nitrate. The lanes on the extreme left and right show the ultra-low molecular mass markers (ULM) and wide-range molecular mass markers (WRM), respectively. 
Screening of these fractions in chick biventer cervicis preparations showed that only RI23 reproduced the activity of RIPS by facilitating the twitch-tension responses prior to causing irreversible neuromuscular blockade. In contrast, fractions RI18, RI19, and RI24 caused only neuromuscular blockade. Analysis of these four peaks by high resolution mass spectrometry (HRMS) with electrospray ionization (ESI) in both modes revealed the presence of the following compounds: $3 \alpha, 12 \beta, 25,26$ tetrahydroxy-7-oxo-5 $\beta$-cholestane-26-O-sulfate, $(5 \beta, 12 \beta)$-12,14-dihydroxy-11-oxobufa-3,20,22-trienolide, $11 \alpha, 19$-di-hydroxy-telocinobufagin, 19-oxo-cinobufagin, argentinogenin, bufogenin B, bufotalin, cinobufagin-3-hemisuberate, marinobufagin, marinoic acid, monohydroxylbufotalin, $N$-methyl-5hydroxytryptamine, and sarmentogenin (Table 1, Figure 2).

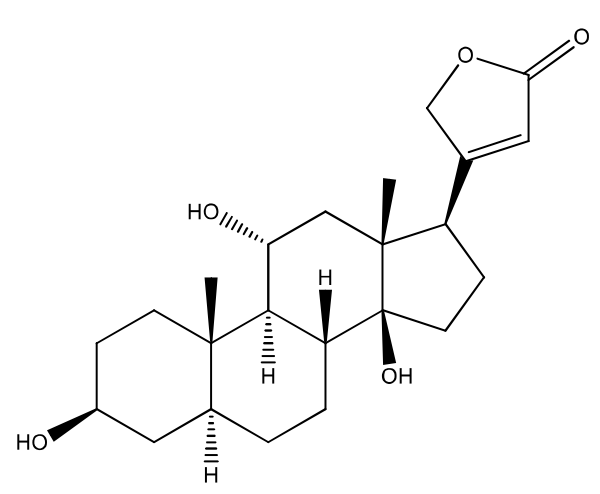

Sarmentogenin

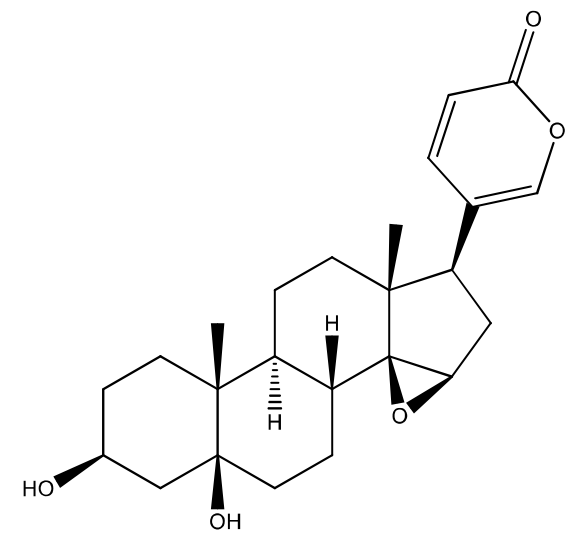

Marinobufagin

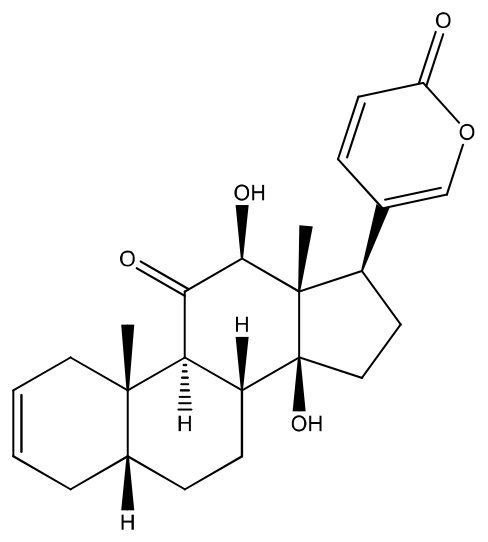

(5,12 )-12,14-dihydroxy-11-oxobuf a-3,20,22-trienolide

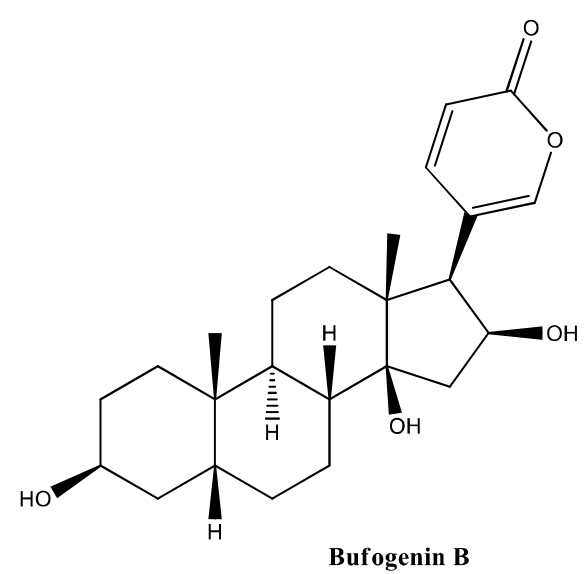<smiles>C[C@]1(C(=O)O)OC(=O)C2C3CC[C@H]4[C@@H](c5ccc(=O)oc5)CC[C@]4(C)[C@]3(C)CC[C@]21C</smiles>

Marinoic acid

Figure 2. Cont. 


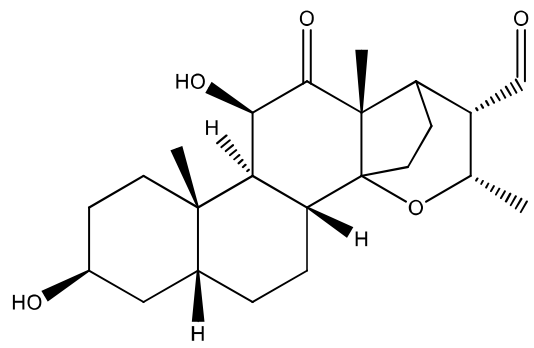

Bufotricosaroide B<smiles>C[C@]12CC[C@@]3(O)C[C@H](O)CC[C@]3(C)C1=C(O)C(=O)[C@]1(C)[C@H](c3ccc(=O)oc3)CC[C@]21O</smiles>

Argentinogenin<smiles>CC(=O)O[C@H]1[C@@H](c2ccc(=O)oc2)[C@@]2(C)CC[C@H]3[C@]4(O)CC[C@@H](O)CC4CC[C@]3(C)[C@]23O[C@H]13</smiles>

19-oxo-Cinobufagin<smiles></smiles>

Cinobuf agin-3-hemisuberate

Figure 2. Chemical structures of the compounds identified by mass spectrometry in fractions RI18, RI19, RI23, and RI24 from R. icterica parotoid secretion. The structures were generated using Chemdraw professional software v.16.0.1.4 (PerkinElmer, Waltham, MA, USA). 
Table 1. Chemical identification of the components of RIPS fractions by high resolution mass spectrometry, in positive and negative electrospray ionization modes $(\mathrm{ESI}(+)$ and $\mathrm{ESI}(-)$, respectively).

\begin{tabular}{|c|c|c|c|c|c|c|c|}
\hline Entry & Precursor Ion $m / z$ & Extract & Identification & Elem. Comp. & Diff ppm & Comp. Type & Ref. \\
\hline \multicolumn{8}{|c|}{ Extract analysis in positive mode ESI(+) } \\
\hline 1 & 191.1171 & RI24 & N-Methyl-5-hydroxytryptamine & $\mathrm{C}_{11} \mathrm{H}_{14} \mathrm{~N}_{2} \mathrm{O}$ & 7.00 & Alkaloid & [40-43] \\
\hline 2 & 391.2497 & RI23 & Sarmentogenin & $\mathrm{C}_{23} \mathrm{H}_{34} \mathrm{O}_{5}$ & 3.20 & Steroid & [44] \\
\hline 3 & $\begin{array}{l}399.2189 \\
399.2182\end{array}$ & $\begin{array}{l}\text { RI18 } \\
\text { RI23 }\end{array}$ & $(5 \beta, 12 \beta)-12,14$-Dihydroxy-11-oxobufa-3,20,22-trienolide & $\mathrm{C}_{24} \mathrm{H}_{30} \mathrm{O}_{5}$ & $\begin{array}{l}4.39 \\
2.63\end{array}$ & Steroid & {$[45,46]$} \\
\hline 4 & $\begin{array}{l}401.2306 \\
401.2318\end{array}$ & $\begin{array}{l}\text { RI18 } \\
\text { RI23 }\end{array}$ & $\begin{array}{c}\text { 14,15-Epoxy-3,5-dihydroxybufa-20,22-dienolide } \\
\text { (marinobufagin) }\end{array}$ & $\mathrm{C}_{24} \mathrm{H}_{32} \mathrm{O}_{5}$ & $\begin{array}{l}5.48 \\
2.50\end{array}$ & Steroid & {$[25,31,47,48]$} \\
\hline 5 & 403.2446 & RI23 & $\begin{array}{c}(3 \beta, 5 \beta, 16 \beta)-3,5,16-\text { Trihydroxy-bufa-14,20,22-dienolide } \\
\text { (Bufogenin B) }\end{array}$ & $\mathrm{C}_{24} \mathrm{H}_{34} \mathrm{O}_{5}$ & 9.55 & Steroid & {$[49,50]$} \\
\hline 6 & $\begin{array}{l}435.2356 \\
433.2266\end{array}$ & $\begin{array}{l}\text { RI19 } \\
\text { RI24 }\end{array}$ & $11 \alpha, 19$-Di-hydroxy-telocinobufagin & $\mathrm{C}_{24} \mathrm{H}_{34} \mathrm{O}_{7}$ & $\begin{array}{l}6.15 \\
9.17\end{array}$ & Steroid & {$[46,51,52]$} \\
\hline 7 & 440.2167 & RI23 & Argentinogenin & $\mathrm{C}_{26} \mathrm{H}_{31} \mathrm{O}_{6}$ & 7.24 & Steroid & {$[44,53]$} \\
\hline 8 & 445.2609 & RI18 & Bufotalin & $\mathrm{C}_{26} \mathrm{H}_{36} \mathrm{O}_{6}$ & 4.24 & Steroid & {$[35,44,54-57]$} \\
\hline 9 & 458.2310 & RI23 & 19-Oxo-cinobufagin & $\mathrm{C}_{26} \mathrm{H}_{32} \mathrm{O}_{7}$ & 1.19 & Steroid & {$[36,44]$} \\
\hline 10 & 461.2481 & RI24 & Monohydroxylbufotalin & $\mathrm{C}_{26} \mathrm{H}_{36} \mathrm{O}_{7}$ & 8.73 & Steroid & [6] \\
\hline 11 & 531.2983 & RI23 & $3 \alpha, 12 \beta, 25,26$-Tetrahydroxy-7-oxo- $5 \beta$-cholestane-26-O-sulfate & $\mathrm{C}_{27} \mathrm{H}_{46} \mathrm{O}_{8} \mathrm{~S}$ & 1.63 & Steroid & [44] \\
\hline 12 & 599.3231 & RI23 & Cinobufagin-3-hemisuberate & $\mathrm{C}_{34} \mathrm{H}_{46} \mathrm{O}_{9}$ & 1.82 & Steroid & [58] \\
\hline \multicolumn{8}{|c|}{ Extract analysis in negative mode ESI(-) } \\
\hline 13 & 433.2266 & RI24 & $\begin{array}{c}11 \alpha, 19-D i-h y d r o x y-t e l o c i n o b u f a g i n ~(M a r i n o s i n) \\
\text { Marinoic acid }\end{array}$ & $\mathrm{C}_{24} \mathrm{H}_{34} \mathrm{O}_{7}$ & 9.17 & Steroid & {$[46,52,53]$} \\
\hline 14 & 431.2116 & RI19 & $\begin{array}{c}\text { (3 } \beta \text {-hydroxy-11,12-seco-5 } \beta, 14 \beta \text {-bufa-20,22-dienolide-11,14- } \\
\text { olide-12-oic acid) }\end{array}$ & $\mathrm{C}_{24} \mathrm{H}_{30} \mathrm{O}_{7}$ & 3.43 & Steroid & {$[59,60]$} \\
\hline
\end{tabular}

Comp. type-component type (broad classification). Elem. comp.-elemental composition. RI-Rhinella icterica. 


\subsection{Neuromuscular Blockade Caused by RIPS and Its Fractions in Chick Biventer Cervicis Preparations}

RIPS and fractions RI18, RI19, RI23, and RI24 were screened for neuromuscular activity in chick biventer cervicis preparations at a single concentration of $10 \mu \mathrm{g} / \mathrm{mL}$ (Figure 3). RIPS caused marked facilitation of the twitch-tension responses (52 $\pm 6 \%$ increase, $n=3 ; p<0.05$ compared to saline control preparations) in field-stimulated preparations that was maximal at $\sim 20$ min after the addition of secretion to the organ and was followed by a progressive decrease in muscle tension until complete abolition of neuromuscular responses after 110-120 min (Figure 3). In contrast to RIPS, RI18 (Figure 3a) and RI19 (Figure 3b) caused only neuromuscular blockade without any prior facilitation. The progressive decrease in muscle twitch-tension caused by these two fractions reflected that seen with RIPS, but was more rapid, with RI18 being more potent (caused quicker blockade) than RI19 (total blockade within $30 \mathrm{~min}$ and $40 \mathrm{~min}$, respectively). RI23 mimicked the response to RIPS in that it caused muscle facilitation that was maximal after $10 \mathrm{~min}(32 \pm 9 \%$ increase in tension, $p<0.05, n=3)$ followed by rapid abolition of twitch-tension responses (total blockade by 20 min after addition to the organ bath compared to 110-120 min for RIPS; Figure 3c). The neuromuscular activity of RI24 differed from the other fractions in that it did not cause muscle facilitation and the blockade it produced was slower, started soon after addition to the organ bath and was incomplete (maximal blockade of $92 \pm 8 \%$ after 110-120 min, $n=3$; Figure 3d); thus, the time-course of the blockade differed completely from that seen with RIPS and RI18, RI19, and RI23. In this same preparation, $0.4 \mathrm{nM}$ ouabain, a specific inhibitor of $\mathrm{Na}^{+} / \mathrm{K}^{+}$-ATPase (NKA), produced a combination of responses that was identical to that seen with RI23 (Figure 3e) and similar to that caused by RIPS. Specifically, there was a transient facilitatory response $(50 \pm 5 \%, n=3)$ that was maximal after $10 \mathrm{~min}$ and greater than that seen with RI23 (see above), followed by complete irreversible neuromuscular blockade within $30 \mathrm{~min}$.

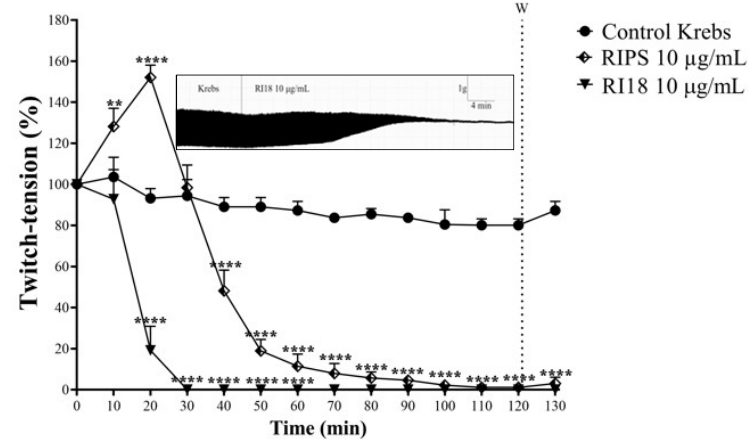

(a)

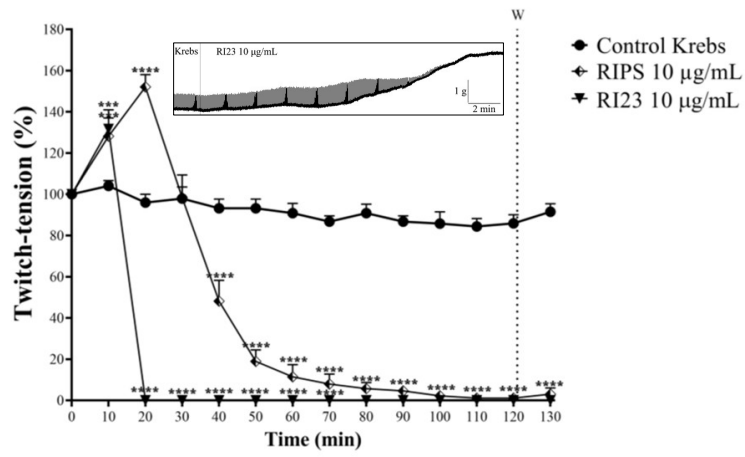

(c)

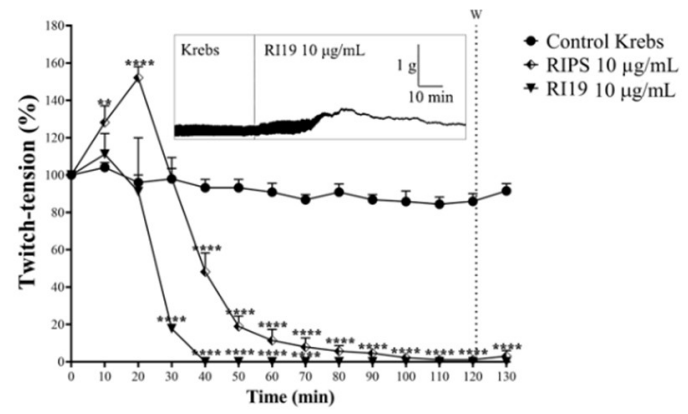

(b)

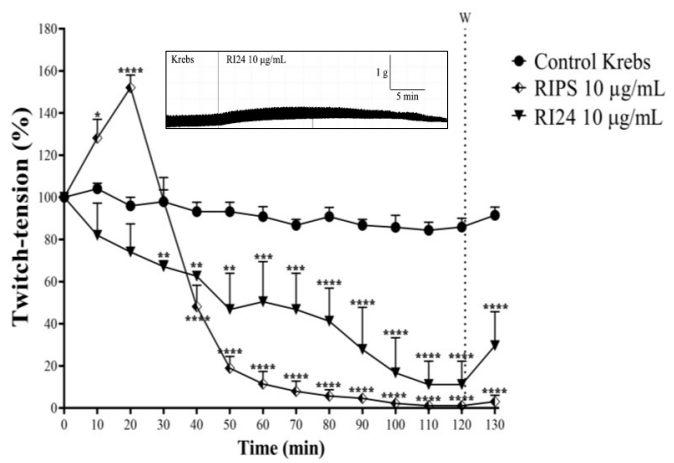

(d)

Figure 3. Cont. 


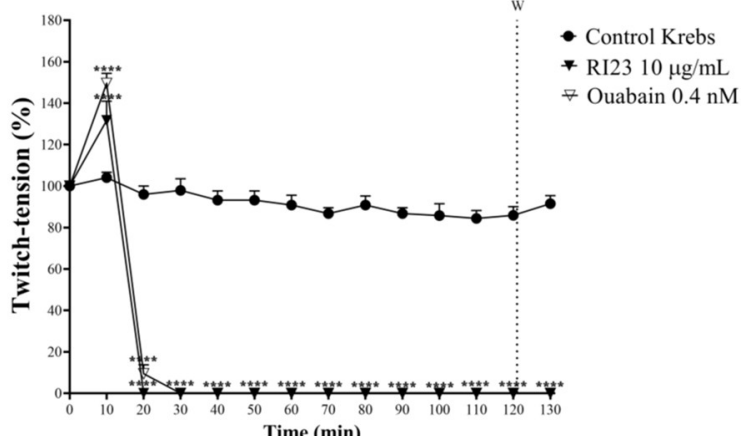

(e)

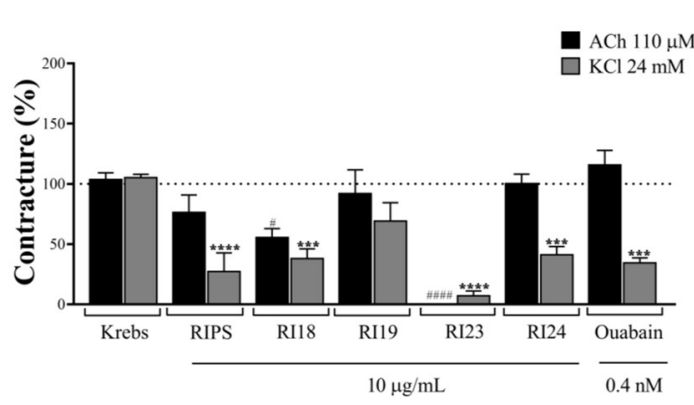

(f)

Figure 3. Neuromuscular effect of RIPS, fractions RI18, RI19, RI23, and RI24, and ouabain in chick biventer cervicis preparations. The panels show the neuromuscular responses to RI18 (a), RI19 (b),

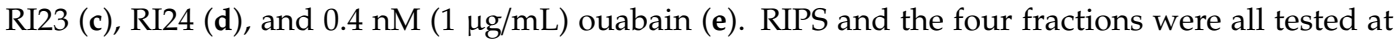
a fixed concentration of $10 \mu \mathrm{g} / \mathrm{mL}$. In all cases, the preparations were stimulated indirectly $(0.5 \mathrm{~Hz}$, $0.2 \mathrm{~ms}, 3-10 \mathrm{~V})$ for $120 \mathrm{~min}$. (f) Contractures to exogenous $\mathrm{ACh}(110 \mu \mathrm{M})$ and $\mathrm{KCl}(24 \mathrm{mM})$ in chick biventer cervicis preparations in the absence and presence of RIPS, the four fractions and ouabain. The results were expressed as the percent response relative to the basal tension (before addition of RIPS, fractions or ouabain) in panels (a-e) and to the basal responses to $\mathrm{ACh}$ and $\mathrm{KCl}$ in panel (f), and are shown as the mean \pm standard error of the mean (S.E.M.) $\left(n=3\right.$ in all cases) ${ }^{*} p<0.05, * * p<0.01$, ${ }^{* * *} p<0.001$ and ${ }^{* * * *} p<0.0001$ compared to the Krebs control in panels (a-e) and the Krebs control for ACh-induced contractures in panel (f); ${ }^{\#} p<0.05$ and ${ }^{\# \# \#} p<0.0001$ compared to the Krebs control for ACh-induced contractures in panel (f).

RIPS and the four fractions had variable effects on the biventer cervicis muscle contractures to exogenous $\mathrm{ACh}$ and $\mathrm{KCl}$. RI18 and RI23 attenuated the responses to $\mathrm{ACh}$ and $\mathrm{KCl}$, with RI23 abolishing the contracture to exogenous $\mathrm{ACh}$ and virtually abolishing the response to $\mathrm{KCl}$ (Figure $3 \mathrm{f}$ ). RI24 reduced the responses only to $\mathrm{KCl}$ and $\mathrm{RI} 19$ had no significant effect on contractures to either agonist, despite a $31 \pm 15 \%$ decrease in the response to $\mathrm{KCl}$ (Figure $3 \mathrm{f}$ ). The contractures to $\mathrm{KCl}$ were more consistently affected by RIPS and fractions RI18, RI23, and RI24 than the responses to ACh (reductions of $73 \pm 15 \%, 61 \pm 10 \%, 91 \pm 5 \%$, and $59 \pm 9 \%$ for RIPS, RI18, RI23, and RI24, respectively; $p<0.05, n=3)$. Under similar conditions, ouabain had no effect on ACh-induced contractures but reduced the responses to $\mathrm{KCl}$ by $66 \pm 4 \%(n=3)$; this profile was similar to that seen with RI24 (Figure 3f).

\subsection{Effect of RIPS Fractions on Acetylcholinesterase (AChE) Activity}

In view of the ability of RIPS and RI23 to cause muscle facilitation prior to blockade, a finding suggestive of ACh accumulation in the skeletal neuromuscular junction, we examined the ability of RIPS and its fractions to inhibit AChE activity in homogenates of chick biventer cervicis preparations that had been incubated with RIPS, RI18, RI19, RI23, or RI24 (10 $\mu \mathrm{g} / \mathrm{mL}$ each) or neostigmine (5 $\mu \mathrm{M}$, a classic AChE inhibitor) during the myographic experiments. All treatments significantly inhibited the AChE activity of the homogenates (Figure 4a). In contrast, the incubation of brain slices with RIPS and its fractions ( $5 \mu \mathrm{g} / \mathrm{mL}$ each) for $1 \mathrm{~h}$ had no marked effect on AChE activity compared to the negative control (HEPES (4-(2-hydroxyethyl)piperazine-1-ethanesulfonic acid) buffer), whereas neostigmine ( $5 \mu \mathrm{M}$, positive control) strongly inhibited this activity (Figure $4 \mathrm{~b})$. 


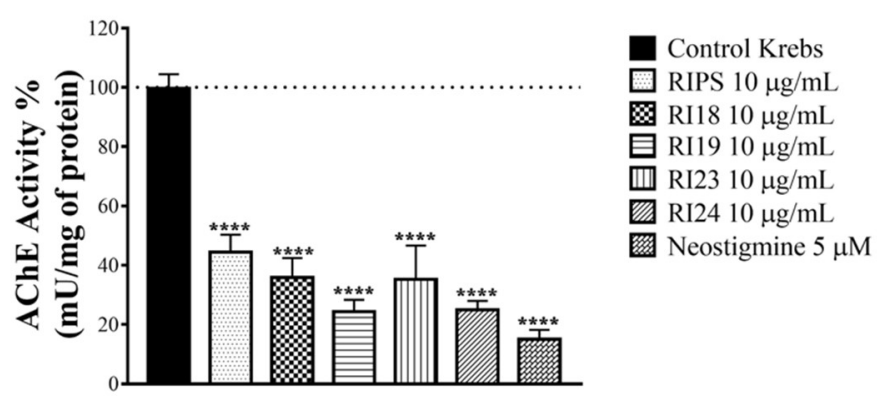

(a)

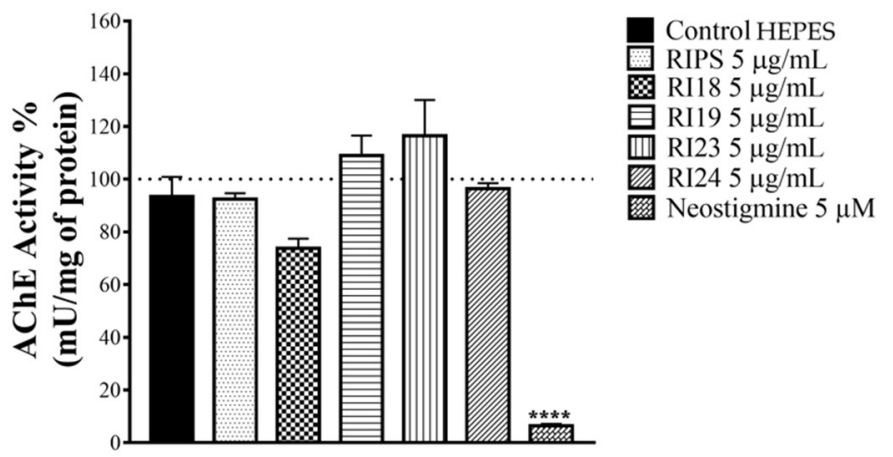

(b)

Figure 4. Modulation of acetylcholinesterase (AChE) activity by RIPS and its fractions. (a) AChE activity in homogenates of chick muscle from biventer cervicis preparations previously incubated with RIPS and its fractions (10 $\mu \mathrm{g} / \mathrm{mL}$ each). (b) AChE activity in chick brain slices incubated with RIPS and its fractions ( $5 \mu \mathrm{g} / \mathrm{mL}$ each). In all experiments, $5 \mu \mathrm{M}$ neostigmine and Krebs or HEPES were used as positive and negative controls, respectively. The columns represent the mean \pm S.E.M. $(n=3)$. **** $p<0.0001$ compared to HEPES or Krebs controls.

\subsection{Effect of RIPS on Propranolol-Induced Neuromuscular Blockade}

In view of the ability of RIPS to inhibit AChE (see above) and its potential inhibition of $\mathrm{Na}^{+} / \mathrm{K}^{+}$-ATPase (based on the identical profiles of RI23 and ouabain in chick biventer cervicis preparations), we compared the effects of RIPS $(10 \mu \mathrm{g} / \mathrm{mL})$ with those of the non-selective $\beta$-blocker propranolol in chick biventer cervicis preparations since propranolol has a similar profile of activity (inhibition of AChE and $\mathrm{Na}^{+} / \mathrm{K}^{+}$-ATPase activities) to that of RIPS. Incubation of chick biventer cervicis preparations with propranolol $(10 \mu \mathrm{g} / \mathrm{mL})$ caused a progressive decrease in the twitch-tension after the addition to the organ bath, with a maximum reduction of $43 \pm 8 \%$ after 120 min (Figure $5 \mathrm{a}$ ). When RIPS was added $60 \mathrm{~min}$ after propranolol, it still produced its characteristic response, but of smaller magnitude and a shorter time scale (complete blockade within $50 \mathrm{~min}$ of RIPS addition, compared to 110-120 min with RIPS alone; Figure 5a). When the order was reversed, i.e., RIPS added before propranolol, the latter had no major effect on the overall shape of the response to RIPS except to shift the curve slightly to the left, indicating a somewhat faster blockade ( $50 \%$ blockade without propranolol in $43 \pm 5 \mathrm{~min}$ compared to $32 \pm 4 \mathrm{~min}$, but the difference was not significant; complete blockade also occurred earlier: after $72 \pm 7$ min compared to 110-120 min with RIPS alone, $p<0.01$, $n=4$; Figure $5 b$ ).

In experiments to examine the effect on the responses to exogenous $\mathrm{ACh}$ and $\mathrm{KCl}$, propranolol $(10 \mu \mathrm{g} / \mathrm{mL})$ markedly attenuated the ACh-induced contractures but did not affect those to $\mathrm{KCl}$. In protocols where propranolol was added before RIPS, this pattern was maintained but more intensely, i.e., greater effect. In contrast, when the order of addition was reversed (RIPS before propranolol) this distinctive pattern was abolished and instead there was a slight but non-significant attenuation in the responses to both $\mathrm{ACh}$ and $\mathrm{KCl}$ (Figure $5 \mathrm{c}$ ). 


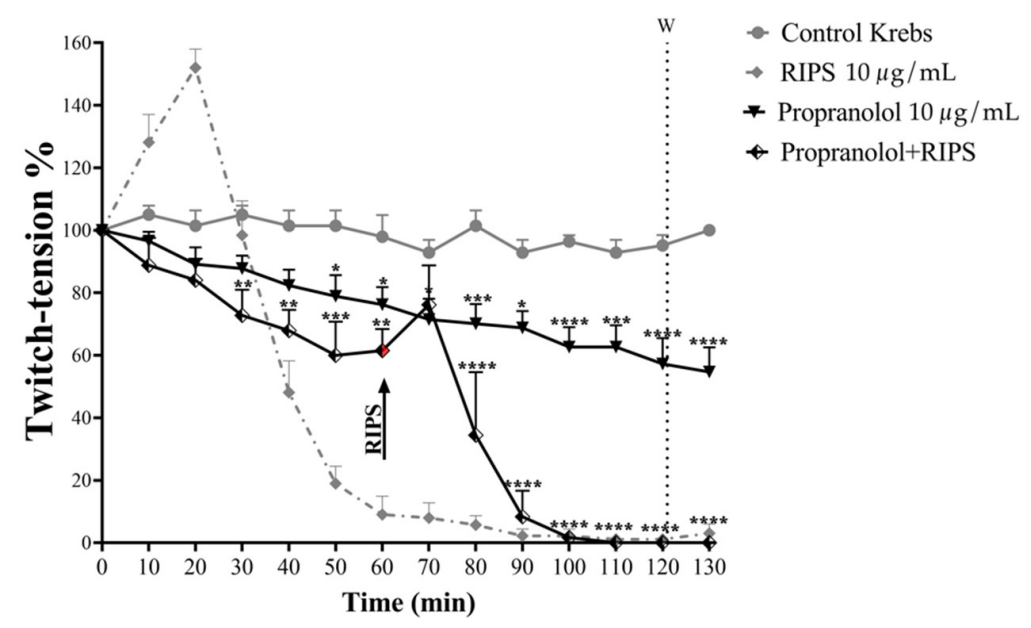

(a)

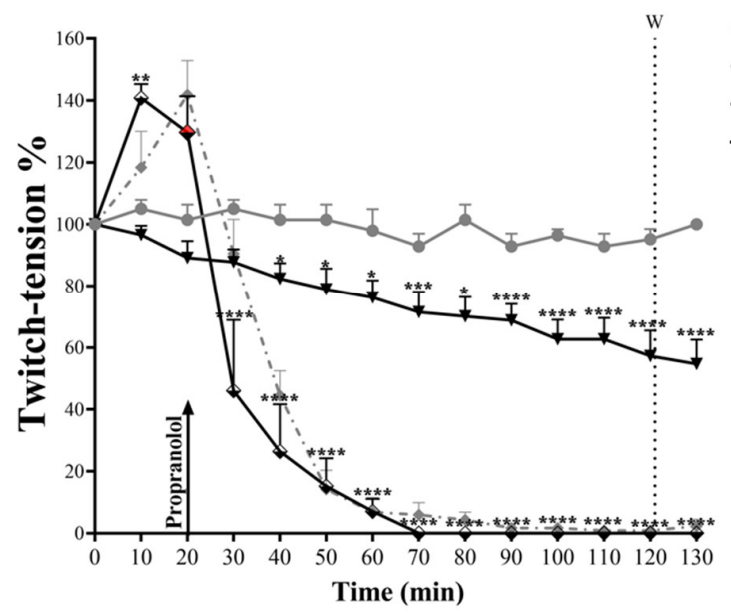

- Control Krebs

$\rightarrow$ RIPS $10 \mu \mathrm{g} / \mathrm{mL}$

- Propranolol $10 \mu \mathrm{g} / \mathrm{mL}$

$\leftarrow$ RIPS+Propranolol

(b)

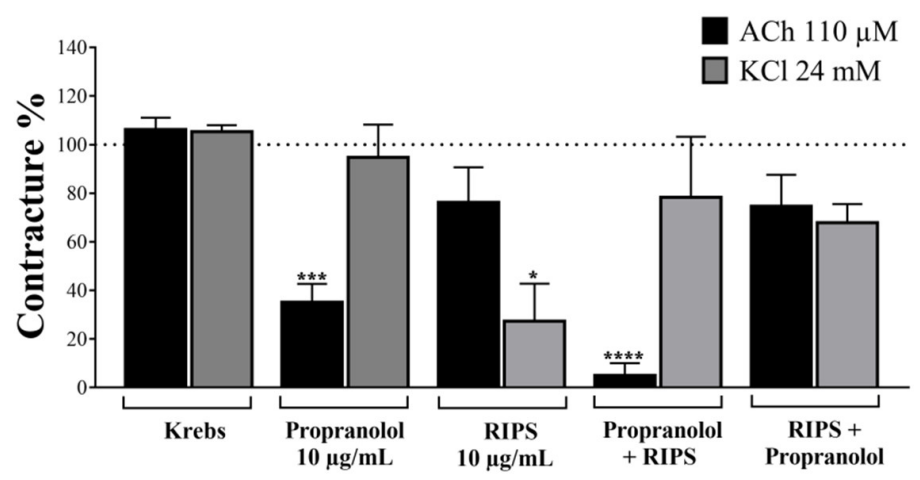

(c)

Figure 5. Effect of RIPS on propranolol-induced neuromuscular responses in chick biventer cervicis preparations. (a) Twitch-tension responses to propranolol $(10 \mu \mathrm{g} / \mathrm{mL}, 38 \mu \mathrm{M})$ alone and to RIPS $(10 \mu \mathrm{g} / \mathrm{mL})$ after preincubation of the preparations with propranolol. (b) Twitch-tension responses to propranolol $(10 \mu \mathrm{g} / \mathrm{mL})$ in preparations preincubated with RIPS $(10 \mu \mathrm{g} / \mathrm{mL})$. (c) Responses to exogenous $\mathrm{ACh}(110 \mu \mathrm{M})$ and $\mathrm{KCl}(24 \mathrm{mM})$. In all protocols, the preparations were stimulated indirectly $(0.5 \mathrm{~Hz}$, $0.2 \mathrm{~ms}, 3-10 \mathrm{~V}$ ) for $120 \mathrm{~min}$ after which they were washed ( $\mathrm{W}$ in panels $\mathbf{a}$ and $\mathbf{b}$ ) to assess the reversibility of the blockade (irreversible in all cases). The responses of negative (Krebs solution alone) and positive (RIPS alone) control preparations are also shown. The points and columns represent the mean \pm S.E.M. $(n=4) .{ }^{*} p<0.05,{ }^{* *} p<0.01,{ }^{* * *} p<0.001$ and ${ }^{* * * *} p<000.1$ compared to preparations incubated with Krebs solution alone. 


\subsection{Cell Viability in the Presence of RIPS and Its Fractions}

We have previously shown that RIPS can partially prevent excitotoxicity in mouse brain slices [39]. To confirm this anti-neurotoxic potential, chick brain slices were incubated with RIPS (5, 10, 20, and $40 \mu \mathrm{g} / \mathrm{mL}$ ) and its four fractions (RI18, RI19, RI23, and RI24; $5 \mu \mathrm{g} / \mathrm{mL}$ each). For RIPS, only the highest concentration tested $(40 \mu \mathrm{g} / \mathrm{mL})$ caused a small decrease $(14 \pm 4 \%)$ in cell viability (Figure 6a). For comparison, digoxin, a known $\mathrm{Na}^{+} / \mathrm{K}^{+}$-ATPase inhibitor, also decreased the viability of chick brain slices by $35 \pm 6 \%$ at the highest concentration tested $(40 \mu \mathrm{g} / \mathrm{mL}$; Figure $6 \mathrm{~b})$. Since RIPS did not adversely affect cell viability in chick brain slices at concentrations up to $5 \mu \mathrm{g} / \mathrm{mL}$, we chose this concentration to screen the RIPS fractions for their effect on cell viability. All subfractions caused a slight but significant decrease in cell viability that ranged from $13 \pm 4 \%$ (RI24) to $23 \pm 2 \%$ (RI19) compared to the negative control (brain slices incubated with HEPES buffer alone). The positive control (hydrogen peroxide, $\mathrm{H}_{2} \mathrm{O}_{2}$ ) reduced cell viability by $\geq 90 \%$ in all cases (Figure $6 \mathrm{c}$ ).

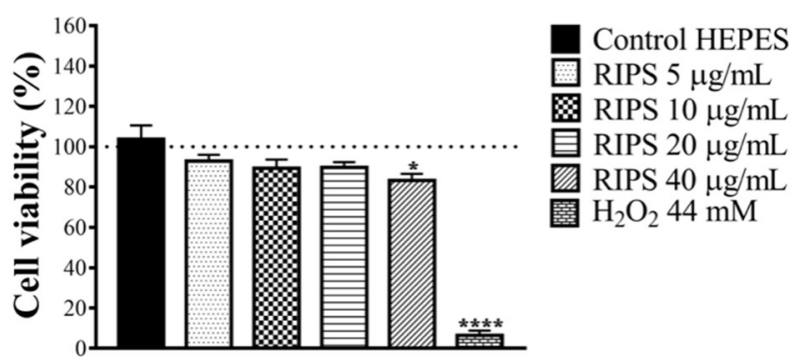

(a)

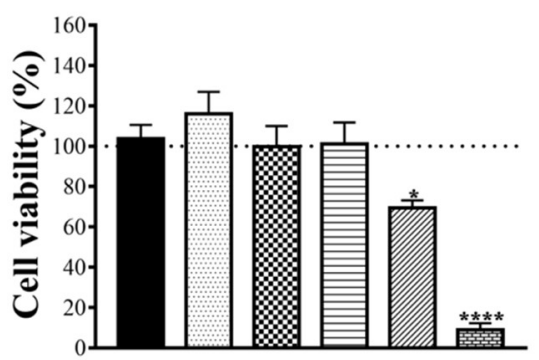

Control HEPES

Digoxin $5 \mu \mathrm{g} / \mathrm{mL}$

Q Digoxin $10 \mu \mathrm{g} / \mathrm{mL}$

目 Digoxin $20 \mu \mathrm{g} / \mathrm{mL}$

שV Digoxin $40 \mu \mathrm{g} / \mathrm{mL}$

臣 $\mathrm{H}_{2} \mathrm{O}_{2} 44 \mathrm{mM}$

(b)

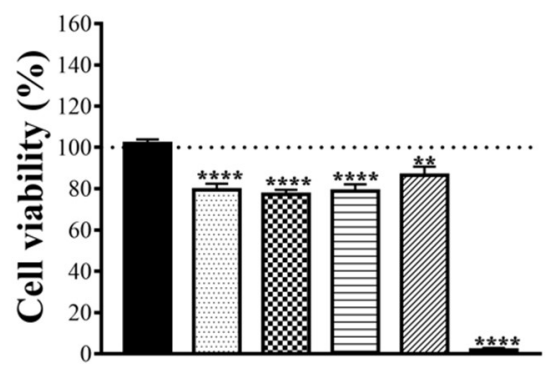

Control HEPES

$\mathrm{RI} 185 \mu \mathrm{g} / \mathrm{mL}$

因 RI19 $5 \mu \mathrm{g} / \mathrm{mL}$

目 RI23 $5 \mu \mathrm{g} / \mathrm{mL}$

VI24 $5 \mu \mathrm{g} / \mathrm{mL}$

瀻 $\mathrm{H}_{2} \mathrm{O}_{2} 44 \mathrm{mM}$

(c)

Figure 6. Effect of RIPS (a), digoxin (b), and RIPS fractions (c) on cell viability in chick brain slices. For the assays, brain slices were incubated with RIPS $(5,10,20$, and $40 \mu \mathrm{g} / \mathrm{mL})$ and fractions RI18, RI19, RI23, and RI24 (all tested at a fixed concentration of $5 \mu \mathrm{g} / \mathrm{mL}$ ) for $60 \mathrm{~min}$ prior to evaluating cell viability in the MTT (3-(4, 5-dimethylthiazol-2-yl)-2, 5-diphenyltetrazolium bromide) reduction assay. Digoxin $(5,10,20$, and $40 \mu \mathrm{g} / \mathrm{mL}), \mathrm{a} \mathrm{Na}^{+} / \mathrm{K}^{+}$-ATPase inhibitor, was included for comparison. The negative and positive controls were HEPES-saline buffer and $44 \mathrm{mM} \mathrm{H}_{2} \mathrm{O}_{2}$, respectively. The columns represent the mean \pm S.E.M. $(n=6) .{ }^{*} p<0.05,{ }^{* *} p<0.01$ and ${ }^{* * *} p<0.0001$ compared to the HEPES control. 


\section{Discussion}

In previous work, we examined the effects of RIPS in insect neurological and neuromuscular preparations [27,39] and in rat cardiac tissue [39]. As a continuation of these investigations, in this study we investigated the activity of RIPS and some of its chromatographic fractions in avian central and peripheral nervous tissue and undertook chemical screening to identify the main compounds associated with the pharmacological activity of RIPS. RP-FPLC of the secretion resulted in four fractions (RI18, RI19, RI23, and RI24) that, together, accounted for the neurobiological activity of RIPS. Analysis of the four fractions by liquid chromatography-diode array detection-mass spectrometry (LC-DAD-MS) identified a variety of compounds (see Table 1) broadly classified as alkaloids and steroids, in addition to marinoic acid and $N$-methyl-5-hydroxytryptamine $[43,59]$.

Of the four fractions, only RI23 completely mimicked the activity of RIPS in chick biventer cervicis preparations in which it produced a biphasic response involving a transitory facilitation of twitch-tension followed by progressive neuromuscular blockade (Figure 3c). The occurrence of facilitation suggested an increase in $\mathrm{ACh}$ release and/or a lack of degradation of this neurotransmitter at the motor endplate [61,62].

We have recently shown that RIPS inhibits $\mathrm{Na}^{+} / \mathrm{K}^{+}$-ATPase activity in rat cardiomyocytes in a manner similar to ouabain [39]. At vertebrate neuromuscular junctions, the inhibition of $\mathrm{Na}^{+} / \mathrm{K}^{+}$-ATPase increases ACh release by inducing depolarization of the motor somatic nerve terminal [62] and can lead to muscle facilitation, as also seen here (Figure 3e). In our experimental conditions, the inhibition of AChE activity by RIPS probably also prevented ACh degradation at chick neuromuscular junctions. This latter pharmacological activity is also shared with propranolol, a non-selective $\beta$-blocker $[63,64]$. Indeed, as shown here, propranolol intensified the neuromuscular blocking activity of RIPS (Figure 5b). This activity of propranolol may be related to its stabilizing effect on the motor endplate membrane, more commonly known as a "local anesthetic" action [63], and suggests that it may share a similar molecular target with RIPS.

The chemical analysis of RI23 indicated a predominance of bufogenins, which are steroidal compounds from toad parotoid secretions that exert a cardiotonic effect via a digoxin- or ouabain-like mechanism $[9,34]$ and the blockade of voltage-dependent L-type calcium channels; one of the best studied bufogenins is bufalin [65]. The findings of our investigation indicate that the pharmacological activity of RI23 at the avian motor endplate involves at least three mechanisms, namely, (1) anti-AChE activity; (2) the inhibition of $\mathrm{Na}^{+} / \mathrm{K}^{+}$-ATPase activity that could contribute to facilitation and subsequent neuromuscular blockade; and (3) the blockade of voltage-dependent $\mathrm{Ca}^{2+}$ channels, possibly mediated by stabilization of the motor endplate membrane.

Screening of the other three fractions (RI18, RI19, and RI24) in chick biventer cervicis muscle preparations showed that they caused only progressive neuromuscular blockade, with no initial facilitation. Chemical analysis of these fractions revealed the presence of serotonin [40], the bufadienoliderelated marinoic acid [59] and the cardiac glycoside-analog bufotalin [57]. The lack of a facilitatory response with these fractions could reflect differences in their chemical composition compared to RI23 or could simply be because they had a lower content of the compound that caused facilitation. Since we did not systematically screen the fractions for their biological activities based on the proportion in which the fractions occurred in RIPS, this question remains unanswered, although the relative order of contribution would likely be similar to that seen here. A further limitation was the fact that we did not investigate the responses to possible combinations of these fractions.

The skin secretion of Rhinella toads contains significant amounts of bufadienolides that are potent cardiac glycosides, as well as catecholamines and indolylalkylamines $[9,40]$. The last of these groups includes $N$-methyl analogs of serotonin ( $N$-methyl-5-hydroxytryptamine). Patten et al. [66] reported serotonin-induced depression of isometric twitches in rat skeletal muscle, and Meltzer et al. [67] suggested a direct effect of serotonin on rat skeletal muscles, independent of vascular changes. At skeletal neuromuscular junctions, serotonin may function as an endogenous allosteric modulator of nicotinic acetylcholine receptors (nAChR) [68]. 
The other components in fractions RI18 and RI19 may intensify the decrease in muscle contractility caused by RIPS, possibly via a propranolol-like stabilizing effect on the postsynaptic membrane [69]. In this regard, it is worth noting that propranolol affected almost exclusively the responses to exogenous $\mathrm{ACh}$, a receptor-mediated phenomenon (that would be most affected by membrane stabilization), compared to the essentially ion-mediated effect of high potassium. Propranolol also slightly potentiated the attenuation of muscle contractility mediated by RIPS in chick neuromuscular preparations (Figure $5 b$ ). The observation that when given after RIPS propranolol had little effect on the response to exogenous ACh could reflect the anti-AChE activity of RIPS that would increase the junctional content of ACh and prevent the binding of propranolol to the nAChR [70].

RIPS and its fractions markedly inhibited muscle AChE activity. Since AChE degrades ACh and terminates the pharmacological activity of this neurotransmitter at cholinergic synapses, we suggest that the anti-AChE activity of RIPS contributes to the transitory facilitation in chick biventer cervicis preparations [70]. The anti-AChE activity of RIPS may also contribute to the progressive neuromuscular blockade by inducing ACh-dependent hyperpolarization of skeletal muscle fibers [71]. The inability of RIPS to inhibit avian brain AChE compared to the muscle enzyme may reflect the insensitivity of this AChE to the secretion, in a manner analogous to the insensitivity of brain AChE to inhibition by fasciculins from mamba snake venoms [72].

As indicated here, RIPS and its fractions showed no neuroprotective activity in the avian central nervous system (chick brain slices); indeed, there was a slight decrease in cell viability, as also seen with digoxin. The four fractions tested showed a slightly greater ability to reduce cell viability than RIPS. This discrepancy may reflect the fact that the fractions were screened in a "purer" state than RIPS and most likely therefore contained a greater amount of active components than unfractionated secretion (a similar argument could also explain the greater effect of fractions RI18, RI19, and RI23 in causing neuromuscular blockade compared to RIPS). Alternatively, the presence of protective (inhibitory) factors in the whole secretion could have attenuated the action of the components of fractions RI18, RI19, RI23, and RI24. During chromatography, these protective factors would be separated from the four fractions, allowing the latter to reduce cell viability to a greater extent than seen with RIPS. Cell viability can be altered by toxic conditions that include the production of reactive oxygen species, excitotoxicity, necrosis and apoptosis [73-76]. In addition, anti-AChE compounds can protect cells from neuronal death and cognitive impairment in neurodegenerative diseases $[31,33,76-80]$. The inhibition of $\mathrm{Na}^{+} / \mathrm{K}^{+}$-ATPase is one of the mechanisms implicated in the cytotoxicity of cardiac glycosides [81]. In $\mathrm{Na}^{+} / \mathrm{K}^{+}$-ATPase inhibition, the resulting elevation in the intracellular concentration of $\mathrm{Na}^{+}$would compromise mitochondrial energetics and the redox balance by blunting the mitochondrial accumulation of $\mathrm{Ca}^{2+}$, thereby contributing to the possible cytotoxicity of cardiac glycosides.

In terms of biotechnological applicability, the facilitatory action of fraction RI23 could indicate a potential use in dystrophic neuromuscular diseases, such as Duchenne and myasthenic syndromes, and as a memory enhancer to treat central nervous system dysfunctions, e.g., Alzheimer's disease, as also suggested for crotamine, a low molecular mass ( $\sim 4.9 \mathrm{kDa})$ basic peptide from Crotalus durissus terrificus (South American rattlesnake) venom [82,83].

\section{Conclusions}

This is the first report to evaluate the effect of RIPS and some of its components in avian central and peripheral neurobiological preparations. The chemical analysis of RIPS revealed the presence of four main fractions (RI18, RI19, RI23, and RI24) that contained at least 13 different compounds, most of which shared chemical identities with steroids and indolylalkylamines. Fraction RI23 reproduced the entire pharmacological profile of the venom and contained bufadienolides and cardiac glycosides. The pharmacological activity of RI23 in the avian peripheral nervous system was complex and reflected interactions with several molecular targets, including $\mathrm{AChE}$, the $\mathrm{Na}^{+} / \mathrm{K}^{+}$-ATPase pump and L-type $\mathrm{Ca}^{2+}$ channels, as well as stabilization of the cell membrane. The similarities of the pharmacological 
profile of RIPS with that of propranolol suggested a novel pharmacological function for the toxins of this secretion. The results of this investigation expand our understanding of the biological activities of RIPS and reinforce the biotechnological potential of its individual compounds.

\section{Materials and Methods}

\subsection{Reagents and Secretion Collection}

All chemicals and reagents used were of the highest purity and were obtained from Sigma-Aldrich (St. Louis, MO, USA), Merck (Rio de Janeiro, RJ, Brazil), or BioRad Laboratories (Hercules, CA, USA). The parotoid secretion was collected as previously described [39] using toads captured near the city of Derrubadas, in the southern Brazilian state of Rio Grande do Sul. The toad capture and secretion collection were authorized by the System of Authorization and Information in Biodiversity (SISBIO, permit $\mathrm{n}^{\mathrm{o}}$. 24867-2). The toad secretion was collected by manual compression of the large post-orbital parotoid glands of adult male and female toads, essentially as described by Leal et al. [27]. The yellowish, viscous secretion was weighed (in liquid form) on a Shimadzu high precision analytical balance. Two grams of liquid RIPS was treated with $50 \mathrm{~mL}$ of methanol for three days at room temperature followed by lyophilization (Liobras, Liotop K105, São Paulo, Brazil) and yielded a powdered extract, as described by Rostelato-Ferreira et al. [84]. This extract was subsequently dispersed in $0.1 \%$ trifluoroacetic acid (TFA) at a concentration of $2 \mathrm{mg} / \mathrm{mL}$, sonicated for $10 \mathrm{~min}$, centrifuged $(5000 \times g, 5 \mathrm{~min})$ and the supernatant was dried, named Rhinella icterica parotoid secretion (RIPS) and used to perform the assays.

\subsection{Animals}

Hyline chicks (1-10 days) were obtained from a local supplier (Agropecuaria Sinuelo, São Gabriel, RS, Brazil). The chicks were housed 15 per cage with water and food ad libitum at $25^{\circ} \mathrm{C}$ on a $12-\mathrm{h}$ light/dark cycle. They were acclimatized for two days prior to use in the experiments. This work was approved by an Institutional Committee for Ethics in Animal Use (CEUA/UNIPAMPA, protocol $n^{\circ}$. 028/2019) and the experiments were done according to the general ethical guidelines for animal use established by the Brazilian Society of Laboratory Animal Science (SBCAL) and Brazilian legislation (Federal Law $\mathrm{n}^{\mathrm{O}}$. 11,794, of 8 October 2008), in conjunction with the guidelines for animal experiments established by the Brazilian National Council for the Control of Animal Experimentation (CONCEA).

\subsection{RP-FPLC of Parotoid Secretion}

In each chromatographic run, $5 \mathrm{~mL}$ of a solution of RIPS $(2 \mathrm{mg} / \mathrm{mL})$ was applied to a reversed-phase C18 column $\left(5 \mu \mathrm{m}, 250 \times 10.0 \mathrm{~mm}, 300 \AA\right.$; Jupiter ${ }^{\circledR}$, Phenomenex) coupled to an Äkta Pure fast protein liquid chromatography (FPLC) system (GE Healthcare, Piscataway, NJ, USA), as described elsewhere [85]. The chromatographic system was operated by Unicorn 5.20 software (General Electric (GE) Healthcare). The column was initially equilibrated with $0.1 \%$ TFA (solution A) and the fractions then eluted with a step-wise gradient $(0-50 \%$ and $50-100 \%)$ of acetonitrile $(60 \%$ acetonitrile in $0.1 \%$ TFA; solution B) until $100 \%$ of solution B was reached. The column was eluted at a flow rate of $1 \mathrm{~mL} / \mathrm{min}$ and the elution profile was monitored at $214 \mathrm{~nm}$. The resulting fractions were collected and stored at $-20^{\circ} \mathrm{C}$ until tested. An aliquot $(2 \mu \mathrm{g})$ of each fraction was dried and resuspended in ultrapure water prior to Tricine-SDS-PAGE [86]). A sample $(60 \mu \mathrm{g})$ of RIPS used for RP-FPLC was also run simultaneously in the same gels as the chromatographic fractions. Ultra-low range molecular mass markers (1060-26,600 Da, Sigma-Aldrich M3546) and wide-range molecular mass markers (6500-200,000 Da, Sigma-Aldrich S8445) were used to estimate the molecular masses of the RIPS components. The gels were run at $85 \mathrm{~V}$, $33 \mathrm{~mA}$, and $3 \mathrm{~W}$ for $4 \mathrm{~h}$ and then stained with silver nitrate [87]. 


\subsection{High Resolution Mass Spectrometry}

For mass spectrometry, the dried fractions were dissolved in a solution consisting of $50 \%(v / v)$ chromatographic grade acetonitrile (Tedia, Fairfild, OH, USA) and $50 \%(v / v)$ deionized water, to which $0.1 \%$ formic acid and $0.1 \%$ ammonium formate had been added, for analysis in positive and negative electrospray ionization modes (ESI(+) and ESI(-), respectively). The individual solutions were infused directly into the ESI source via a syringe pump (Harvard Apparatus, Hamilton, Reno, NV, USA), at a flow rate of $180 \mu \mathrm{L} / \mathrm{min}$. The ESI(+)-and ESI(-) mass spectrometric (MS) and tandem MS-MS profiles were acquired using a hybrid high-resolution and high-accuracy $(5 \mu \mathrm{L} / \mathrm{L})$ micrOTOF-Q mass spectrometer (Bruker Scientific ${ }^{\circledR}$, Billerica, MA, USA) under the following conditions: capillary and cone voltages were set to +3500 and $+40 \mathrm{~V}$, respectively, with a desolvation temperature of $200{ }^{\circ} \mathrm{C}$. The collision-induced dissociation energy (CID) for the ESI(+) MS-MS was optimized for each component. The diagnostic ions were identified by comparison of their dissociation patterns, exact mass and isotopic ratio, with compounds identified in previous studies. For data acquisition and processing, time-of-flight (TOF) control and data analysis software (Bruker Scientific ${ }^{\circledR}$ ) was used. The data were collected in the 70-1200 m/z range, at a rate of two scans/s, providing 50,000 full width at half maximum (FWHM) resolution at $200 \mathrm{~m} / \mathrm{z}$. No important ions were observed below $90 \mathrm{~m} / \mathrm{z}$ and above $950 \mathrm{~m} / \mathrm{z}$, so the ESI(+)-MS data are shown for the range of $90-950 \mathrm{~m} / \mathrm{z}$.

\subsection{Biological Assays}

\subsubsection{Tissue Slice Preparation and Treatment}

The chicks were euthanized by decapitation under anesthesia with halothane and the brain was dissected and placed in HEPES ((4-(2-hydroxyethyl)piperazine-1-ethanesulfonic acid))-saline buffer $\left(124 \mathrm{mM} \mathrm{NaCl}, 4 \mathrm{mM} \mathrm{KCl}, 1.2 \mathrm{mM} \mathrm{MgSO}_{4}, 12 \mathrm{mM}\right.$ glucose, $1 \mathrm{mM} \mathrm{CaCl}_{2}$, and $25 \mathrm{mM}$ HEPES, pH 7.4) at $4{ }^{\circ} \mathrm{C}$. The solution was previously oxygenated for $30 \mathrm{~min}$. The cortical region of the brain was separated and slices $400 \mu \mathrm{m}$ thick were prepared with a Mcllwain tissue slicer [88]. The diameter of the slices was standardized using $3 \mathrm{~mm}$ circular tissue cutters or punches. The tissue slices were subsequently transferred to 96-well plates containing HEPES-saline buffer ( $200 \mu \mathrm{L} / \mathrm{slice})$. After a $30 \mathrm{~min}$ pre-incubation, the buffer was replaced with control solutions (HEPES-saline as the negative control and $44 \mathrm{mM} \mathrm{H}_{2} \mathrm{O}_{2}$ as the positive control) or fractions (RI18, RI19, RI23, RI24) and incubated at $37^{\circ} \mathrm{C}$ for $60 \mathrm{~min}$. All fractions were dissolved in HEPES-saline buffer and were tested at a fixed concentration of $5 \mu \mathrm{g} / \mathrm{mL}$. The concentrations used here were based on previous work by our group which showed that RIPS caused maximum neuromuscular interference, $\mathrm{AChE}$ inhibition and a reduction in cell viability at concentrations of $5-10 \mu \mathrm{g} / \mathrm{mL}$ [39].

\subsubsection{Cell Viability}

The colorimetric MTT (3-(4, 5-dimethylthiazol-2-yl)-2, 5-diphenyltetrazolium bromide) reduction assay based on cellular oxidative metabolism was used to assess cell viability [73]. The assay was done using chick brain slices in the absence or presence of RIPS fractions. Immediately after incubation as described above, the slices were placed in HEPES-saline containing $0.05 \%$ MTT at $37^{\circ} \mathrm{C}$ for $30 \mathrm{~min}$. During this period, the MTT was converted into a purple formazan product after cleavage of the tetrazolium ring by dehydrogenases. The formazan was subsequently dissolved by adding $100 \%$ dimethyl sulfoxide (DMSO), resulting in a colored compound that could be monitored by reading the absorbance at $490 \mathrm{~nm}$ in a Biotek ELx800 multi-well plate reader (Biotek Instruments, Winooski, VT, USA); the results were analyzed with Gen5 Data Analysis software (Biotek Instruments).

\subsubsection{Chick Biventer Cervicis Preparation}

Chick biventer cervicis neuromuscular preparations were used to characterize the neuromuscular activity of RIPS fractions. The chicks were killed with an overdose of anesthetic (halothane) and the biventer cervicis muscle and associated nerve were isolated and mounted as described by Ginsborg and 
Warriner [89]. The muscles were mounted (tension: $0.5 \mathrm{~g} / \mathrm{cm}$ ) in $5 \mathrm{~mL}$ isolated organ baths (AVS Projetos, São Paulo, SP, Brazil) containing Krebs solution of the following composition (in mM): $\mathrm{NaCl} \mathrm{136,}$ $\mathrm{KCl}$ 5, $\mathrm{CaCl}_{2}$ 2.5, $\mathrm{MgSO}_{4} 1.2, \mathrm{KH}_{2} \mathrm{PO}_{4} 1.2, \mathrm{NaHCO}_{3} 23.8$, and glucose 11, $\mathrm{pH} 7.5$. The solution was aerated with a mixture of $95 \% \mathrm{O}_{2}$ and $5 \% \mathrm{CO}_{2}$ at $37{ }^{\circ} \mathrm{C}$. Bipolar electrodes positioned in the region between the tendon and muscle were used to apply field stimulation with supramaximal electrical stimuli (frequency: $0.5 \mathrm{~Hz}$; duration: $0.2 \mathrm{~ms}$ ) delivered from a digital stimulator (model 100-C4, AVS Projetos). Muscle twitches were recorded via isometric transducers coupled to an amplifier and AQCAD software (AVS Projetos). The preparations were stabilized for 20 min prior to testing the fractions that were added in a fixed concentration of $10 \mu \mathrm{g} / \mathrm{mL}$. The potential influence of RIPS and its fractions on postsynaptic cholinergic nicotinic receptors (indicative of neurotoxicity) and skeletal muscle fibers (indicative of myotoxicity) was assessed by comparing the contractile responses to $110 \mu \mathrm{M}$ ACh and $24 \mathrm{mM} \mathrm{KCl}$, respectively, before (basal responses) and after incubation with the secretion and fractions [90]. Muscle contractile responses were recorded for $120 \mathrm{~min}$ after the addition of RIPS or fractions.

\subsubsection{Acetylcholinesterase (AChE) Activity}

The influence of RIPS fractions on AChE activity was assayed according to Ellman et al. [91] using chick brain slices and chick biventer cervicis muscle homogenates. Chick brain slices (a pool of eight slices incubated for $1 \mathrm{~h}$ with RIPS fraction) or each biventer cervicis muscle (collected at the end of the protocols described in the previous section) were homogenized (2000 rpm, $1 \mathrm{~min}$ ) in $750 \mu \mathrm{L}$ of phosphate-buffered saline (PBS; pH 7.0) using a bead-based homogenizer (Powerlyzer, MO BIO Laboratories, Inc., Carlsbad, CA, USA) and then centrifuged $\left(1000 \times g, 5 \mathrm{~min}, 4{ }^{\circ} \mathrm{C}\right)$. A $50 \mu \mathrm{L}$ aliquot of the resulting supernatant was mixed with $50 \mathrm{mM}$ DTNB (5,50-dithiobis-(2-nitrobenzoic acid)) and the reaction was monitored at $405 \mathrm{~nm}$ in a Biotek ELx800 multi-well plate reader and analyzed with Gen5 Data Analysis software. Protein concentrations were determined using the Bradford dye-binding method [92]. The results were expressed as milliunits of AChE/mg protein ( $\mathrm{mU} / \mathrm{mg}$ protein), with one milliunit of activity defined as the amount of enzyme that produced $1 \mathrm{nmol}$ of TNB (2-nitro-5-thiobenzoic acid)/min under the specified conditions.

\subsection{Statistical Analysis}

The data were expressed as the mean \pm standard error of the mean (S.E.M.) and each experiment was repeated at least three times. Data from three or more experimental groups were analyzed by one-way ANOVA followed by Dunnett's test (the groups were compared with a positive control or saline) or two-way ANOVA followed by the Tukey test, with a value of $p<0.05$ indicating significance. All statistical analyses were done using GraphPad Prism 6.0 (Software Inc., San Diego, CA, USA).

Author Contributions: C.A.D.B., R.S.O., A.P.C. and E.C.A. conceived the investigation, R.S.O., B.T.B., A.P.L., K.d.C.F.B., S.M. and M.M.L. did the experimental work, R.S.O., K.d.C.F.B., M.M.L., S.M., B.T.B., A.P.L. and L.V. analyzed and validated the data and prepared the results for publication, C.A.D.B., E.C.A. and T.G.d.S. provided resources, C.A.D.B., V.Q.d.S. and L.V. provided funding, R.S.O. and C.A.D.B. wrote the original draft, with subsequent reviewing, editing and validation by S.H. and A.P.C. C.A.D.B., E.C.A., A.P.C. and L.V. provided supervision and C.A.D.B. was responsible for general administration of the project. All authors read and agreed with the published version of the manuscript.

Funding: This research was supported by PRONEM/FAPERGS/CNPq (grant $n^{\circ}$. 003/2011), Coordenação de Aperfeiçoamento de Pessoal de Nível Superior (CAPES, Finance code 001), CAPES Toxinologia (grant $n^{\circ}$. 063/2010, Finance code 001), PROPESQ/PROPG/PROPPI UNIPAMPA, and Conselho Nacional de Desenvolvimento Científico e Tecnológico (CNPq). The article publishing charges were covered by UNIPAMPA (Edital 02/2020 Apoio ao Custeio de Publicacão Cientifica). APL, BTB and RSO were supported by postgraduate scholarships from CAPES (Finance code 001). VQS is supported by a CNPq category 2 research fellowship (grant $n^{\circ}$. 312329/2019-9).

Acknowledgments: We thank PRONEM/FAPERGS/CNPq, CAPES, CAPES Toxinologia, PROPESQ/PROPG/ PROPPI UNIPAMPA, and CNPq for financial support.

Conflicts of Interest: The authors declare no conflict of interest. 


\section{References}

1. Frost, D.R. Amphibian Species of the World: An Online Reference; American Museum of Natural History: New York, NY, USA, 2019. Available online: http://research.amnh.org/herpetology/amphibia/index.html (accessed on 16 July 2019).

2. Marques, A.A.B. Lista das Espécies da Fauna Ameaçadas de Extinção no Rio Grande do Sul. Decreto n. 41.672, de 11 junho de 2002, FZB/MCT-PUCRS/PANGEA, Porto Alegre, 00155. 2002. Available online: http://www.tecniflora.com.br/fauna_ameacada_RS.pdf (accessed on 16 July 2019).

3. Segalla, M.V.; Caramaschi, U.; Cruz, C.A.G.; Garcia, P.C.A.; Grant, T.; Haddad, C.F.B.; Santana, D.J.; Toledo, L.F.; Langone, J.A. Herpetologia Brasileira; Sociedade Brasileira de Herpetologia, 2019. Available online: http://sbherpetologia.org.br/wp-content/uploads/2019/05/hb-2019-01.pdf (accessed on 14 July 2019).

4. Kowalski, K.; Marciniak, P.; Rosiński, G.; Rychlik, L. Toxic activity and protein identification from the parotoid gland secretion of the common toad Bufo bufo. Comp. Biochem. Physiol. C Toxicol. Pharmacol. 2018, 205, 43-52. [CrossRef]

5. Qi, J.; Zulfiker, A.H.M.; Li, C.; Good, D.; Wei, M.Q. The development of toad toxins as potential therapeutic agents. Toxins 2018, 10, 336. [CrossRef] [PubMed]

6. Rodríguez, C.; Rollins-Smith, L.; Ibáñez, R.; Durant-Archibold, A.A.; Gutiérrez, M. Toxins and pharmacologically active compounds from species of the family Bufonidae (Amphibia, Anura). J. Ethnopharmacol. 2017, 198, 235-254. [CrossRef] [PubMed]

7. Shaw, C. Advancing drug discovery with reptile and amphibian venom peptides-Venom-based medicines. Biochemist 2009, 31, 34-37. [CrossRef]

8. De Waard, M.; Sabatier, J.M. Structure-function strategies to improve the pharmacological value of animal toxins. In Handbook of Biologically Active Peptides; Kastin, A.J., Ed.; Elsevier: New York, NY, USA, 2006; pp. 415-419. [CrossRef]

9. Bücherl, W.; Buckley, E.E. (Eds.) Venomous Animals and their Venoms. Vol. 2. Venomous Vertebrates; Academic Press: New York, NY, USA, 1971. [CrossRef]

10. Saporito, R.A.; Donnelly, M.A.; Spande, T.F.; Garraffo, H.M. A review of chemical ecology in poison frogs. Chemoecology 2012, 22, 159-168. [CrossRef]

11. Xu, X.; Lai, R. The chemistry and biological activities of peptides from amphibian skin secretions. Chem. Rev. 2015, 115, 1760-1846. [CrossRef]

12. Daly, J.W. The chemistry of poisons in amphibian skin. Proc. Natl. Acad. Sci. USA 1995, 92, 9-13. [CrossRef]

13. Sciani, J.M.; Angeli, C.B.; Antoniazzi, M.M.; Jared, C.; Pimenta, D.C. Differences and similarities among parotoid macrogland secretions in South American toads: A preliminary biochemical delineation. Sci. World J. 2013, 2013, 937407. [CrossRef]

14. Toledo, R.C.; Jared, C. Cutaneous granular glands and amphibian venoms. Comp. Biochem. Physiol. 1995, 111, 1-29. [CrossRef]

15. Cunha-Filho, G.A.; Resck, I.S.; Cavalcanti, B.C.; Pessoa, C.Ó.; Moraes, M.O.; Ferreira, J.R.O.; Rodrigues, F.A.R.; dos Santos, M.L. Cytotoxic profile of natural and some modified bufadienolides from toad Rhinella schneideri parotoid gland secretion. Toxicon 2010, 56, 339-348. [CrossRef]

16. Jared, S.G.S.; Jared, C.; Egami, M.I.; Mailho-Fontana, P.L.; Rodrigues, M.T.; Antoniazzi, M.M. Functional assessment of toad parotoid macroglands: A study based on poison replacement after mechanical compression. Toxicon 2014, 87, 92-103. [CrossRef]

17. Li, B.J.; Tian, H.Y.; Zhang, D.M.; Lei, Y.H.; Wang, L.; Jiang, R.W.; Ye, W.C. Bufadienolides with cytotoxic activity from the skins of Bufo bufo gargarizans. Fitoterapia 2015, 105, 7-15. [CrossRef]

18. Sousa, L.Q.; Machado, K.C.; Oliveira, S.F.D.C.; Araújo, L.S.; Monção-Filho, E.S.; Melo-Cavalcante, A.A.C.; Vieira-Júnior, G.M.; Ferreira, P.M.P. Bufadienolides from amphibians: A promising source of anticancer prototypes for radical innovation, apoptosis triggering and $\mathrm{Na}^{+} / \mathrm{K}^{+}$-ATPase inhibition. Toxicon 2017, 127, 63-76. [CrossRef] [PubMed]

19. Xin, X.L.; Lan, R.; Huang, J.; Wang, X.J.; Jia, J.M. A new cytotoxic bufadienolide from Chinese medicine Chansu. Chin. Chem. Lett. 2008, 19, 1445-1446. [CrossRef]

20. Ye, M.; Guo, H.; Guo, H.; Han, J.; Guo, D. Simultaneous determination of cytotoxic bufadienolides in the Chinese medicine ChanSu by high-performance liquid chromatography coupled with photodiode array and mass spectrometry detections. J. Chromatogr. B 2006, 838, 86-95. [CrossRef] [PubMed] 
21. Gadelha, I.C.N.; De Lima, J.M.; Batista, J.S.; Melo, M.M.; Soto-Blanco, B. Toxicity effects of toad (Rhinella jimi Stevaux, 2002) venom in chicken (Gallus gallus domesticus). Sci. World J. 2014, 2014, 1-6. [CrossRef]

22. Da Mata, É.C.G.; Mourão, C.B.F.; Rangel, M.; Schwartz, E.F. Antiviral activity of animal venom peptides and related compounds. J. Venom. Anim. Toxins Incl. Trop. Dis. 2017, 23, 3. [CrossRef]

23. Pettit, G.R.; Kamano, Y. Bufadienolides. 21. Synthesis of cinobufagin from bufotalin. J. Org. Chem. 1972, 37, 4040-4044. [CrossRef]

24. Oliveira, A.F.; Castoldi, L.; Vieira Junior, G.M.; Monção Filho, E.S.; Chaves, M.H.; Rodrigues, D.J.; Sugui, M.M. Evaluation of antimutagenic and cytotoxic activity of skin secretion extract of Rhinella marina and Rhaebo guttatus (Anura, Bufonidae). Acta Amaz. 2019, 49, 145-151. [CrossRef]

25. Cunha Filho, G.A.; Schwartz, C.A.; Resck, I.S.; Murta, M.M.; Lemos, S.S.; Castro, M.S.; Kyaw, C.; Pires, O.R., Jr.; Leite, J.R.S.; Bloch, C., Jr.; et al. Antimicrobial activity of the bufadienolides marinobufagin and telocinobufagin isolated as major components from skin secretion of the toad Bufo rubescens. Toxicon 2005, 45, 777-782. [CrossRef]

26. Tempone, A.G.; Pimenta, D.C.; Lebrun, I.; Sartorelli, P.; Taniwaki, N.N.; de Andrade, H.F.; Antoniazzi, M.M.; Jared, C. Antileishmanial and antitrypanosomal activity of bufadienolides isolated from the toad Rhinella jimi parotoid macrogland secretion. Toxicon 2008, 52, 13-21. [CrossRef] [PubMed]

27. Leal, A.P.; Oliveira, R.S.; Perin, A.P.A.; Borges, B.T.; Vieira, P.B.; dos Santos, T.G.; Valsecchi, C.; Vinadé, L.; Belo, C.A.D. Entomotoxic activity of Rhinella icterica (Spix, 1824) toad skin secretion in Nauphoeta cinerea cockroaches: An octopamine-like modulation. Pestic. Biochem. Physiol. 2018, 148, 175-181. [CrossRef] [PubMed]

28. Supratman, U.; Fujita, T.; Akiyama, K.; Hayashi, H. New insecticidal bufadienolide, bryophyllin C, from Kalanchoe pinnata. Biosci. Biotechnol. Biochem. 2000, 64, 1310-1312. [CrossRef] [PubMed]

29. Neerati, P. Detection of antidiabetic activity by crude paratoid gland secretions from common Indian toad (Bufomelano stictus). J. Nat. Sci. Biol. Med. 2015, 6, 429-433. [CrossRef] [PubMed]

30. Schmeda-Hirschmann, G.; Quispe, C.; Theoduloz, C.; De Sousa, P.T.; Parizotto, C. Antiproliferative activity and new argininyl bufadienolide esters from the "cururú" toad Rhinella (Bufo) schneideri. J. Ethnopharmacol. 2014, 155, 1076-1085. [CrossRef]

31. Schmeda-Hirschmann, G.; Quispe, C.; Arana, G.V.; Theoduloz, C.; Urra, F.A.; Cárdenas, C. Antiproliferative activity and chemical composition of the venom from the Amazonian toad Rhinella marina (Anura: Bufonidae). Toxicon 2016, 121, 119-129. [CrossRef]

32. Vallejo, J.R.; González, J.A. Los anfibios en la medicina popular española, la farmacopea de Plinio y el Dioscórides. História Ciências Saúde Manguinhos 2015, 22, 1283-1319. [CrossRef]

33. Shen, S.; Zhang, Y.; Wang, Z.; Zhang, R.; Gong, X. Bufalin induces the interplay between apoptosis and autophagy in glioma cells through endoplasmic reticulum stress. Int. J. Biol. Sci. 2014, 10, 212-224. [CrossRef]

34. Zhang, P.; Cui, Z.; Liu, Y.; Wang, D.; Liu, N.; Yoshikawa, M. Quality evaluation of traditional Chinese drug toad venom from different origins through a simultaneous determination of bufogenins and indole alkaloids by HPLC. Chem. Pharm. Bull. 2005, 53, 1582-1586. [CrossRef]

35. Ferreira, P.M.P.; Lima, D.J.B.; Debiasi, B.W.; Soares, B.M.; Machado, K.C.; Noronha, J.C.; Rodrigues, D.J.; Sinhorin, A.P.; Pessoa, C.; Vieira Júnior, G.M. Antiproliferative activity of Rhinella marina and Rhaebo guttatus venom extracts from southern Amazon. Toxicon 2013, 72, 43-51. [CrossRef]

36. Mailho-Fontana, P.L.; Antoniazzi, M.M.; Sciani, J.M.; Pimenta, D.C.; Barbaro, K.C.; Jared, C. Morphological and biochemical characterization of the cutaneous poison glands in toads (Rhinella marina group) from different environments. Front. Zool. 2018, 15, 46. [CrossRef] [PubMed]

37. Colombo, P.; Kindel, A.; Vinciprova, G.; Krause, L. Composição e ameaças à conservação dos anfíbios anuros do Parque Estadual de Itapeva, município de Torres, Rio Grande do Sul, Brasil. Biota Neotrop. 2008, 8, 229-240. [CrossRef]

38. Pinto, É.G.; Felipe, A.C.; Nadaletto, D.; Rall, V.L.M.; Martinez, R.M. Investigação da atividade antimicrobiana do veneno de Rhinella icterica (Amphibia, Anura). Rev. Inst. Adolfo Lutz 2009, 68, 471-475.

39. Oliveira, R.S.; Leal, A.P.; Ogata, B.; de Almeida, C.G.M.; dos Santos, D.S.; Lorentz, L.H.; Moreira, C.M.; Bordon, K.C.F.; Arantes, E.C.; dos Santos, T.G.; et al. Mechanism of Rhinella icterica (Spix, 1824) toad poisoning using in vitro neurobiological preparations. Neurotoxicology 2018, 65, 264-271. [CrossRef] [PubMed] 
40. Kryukova, E.V.; Lebedev, D.S.; Ivanov, I.A.; Ivanov, D.A.; Starkov, V.G.; Tsetlin, V.I.; Utkin, Y.N. N-methyl serotonin analogues from the Bufo bufo toad venom interact efficiently with the $\alpha 7$ nicotinic acetylcholine receptors. Biochem. Biophys. Mol. Biol. 2017, 472, 52-55. [CrossRef]

41. Ben-Harari, R.R.; Dalton, B.A.; Osman, R.; Maayani, S. Kinetic characterization of 5-hydroxytryptamine receptor desensitization in isolated guinea-pig trachea and rabbit aorta. J. Pharmacol. Exp. Ther. 1991, 257, 416-424. [PubMed]

42. Zhang, Y.; Takagi, N.; Yuan, B.; Zhou, Y.; Si, N.; Wang, H.; Yang, J.; Wei, X.; Zhao, H.; Bian, B. The protection of indolealkylamines from LPS-induced inflammation in zebrafish. J. Ethnopharmacol. 2019, 243, 112122. [CrossRef]

43. Zhang, Y.; Yuan, B.; Takagi, N.; Wang, H.; Zhou, Y.; Si, N.; Yang, J.; Wei, X.; Zhao, H.; Bian, B. Comparative analysis of hydrophilic ingredients in toad skin and toad venom using the UHPLC-HR-MS/MS and UPLC-QqQ-MS/MS methods together with the anti-inflammatory evaluation of indolealkylamines. Molecules 2019, 24, 86. [CrossRef] [PubMed]

44. Ren, W.; Han, L.; Luo, M.; Bian, B.; Guan, M.; Yang, H.; Han, C.; Li, N.; Li, T.; Li, S.; et al. Multi-component identification and target cell-based screening of potential bioactive compounds in toad venom by UPLC coupled with high-resolution LTQ-Orbitrap MS and high-sensitivity Qtrap MS. Anal. Bioanal. Chem. 2018, 410, 4419-4435. [CrossRef] [PubMed]

45. Kamboj, A.; Rathour, A.; Kaur, M. Bufadienolides and their medicinal utility: A review. Int. J. Pharm. Pharm. Sci. 2013, 5, 20-27.

46. Tian, H.Y.; Zhang, P.W.; Liu, J.S.; Zhang, D.M.; Zhang, X.Q.; Jiang, R.W.; Ye, W.C. New cytotoxic C-3 dehydrated bufadienolides from the venom of Bufo bufo gargarizans. Chin. Chem. Lett. 2014, 25, 1104-1106. [CrossRef]

47. Schoner, W.; Scheiner-Bobis, G. Endogenous cardiac glycosides: Hormones using the sodium pump as signal transducer. Semin. Nephrol. 2005, 25, 343-351. [CrossRef] [PubMed]

48. Bagrov, A.Y.; Shapiro, J.I.; Fedorova, O.V. Endogenous cardiotonic steroids: Physiology, pharmacology, and novel therapeutic targets. Pharmacol. Rev. 2009, 61, 9-38. [CrossRef] [PubMed]

49. Liu, J.; Zhang, D.; Li, Y.; Chen, W.; Ruan, Z.; Deng, L.; Wang, L.; Tian, H.; Yiu, A.; Fan, C.; et al. Discovery of bufadienolides as a novel class of ClC-3 chloride channel activators with antitumor activities. J. Med. Chem. 2013, 56, 5734-5743. [CrossRef]

50. Meng, L.; Jiang, N.; Yu, C.; Li, S.; Chun, Z.; Zhu, X.; Song, C.; Xiao, Y.; Hui, J.; Qin, Y.; et al. Bufadienolides from the skins of Bufo melanosticus and their cytotoxic activity. Phytochem. Lett. 2019, 31, 73-77. [CrossRef]

51. Matsukawa, M.; Akizawa, T.; Ohigashi, M.; Morris, J.F.; Butler, V.P., Jr.; Yoshioka, M. A novel bufadienolide, marinosin, in the skin of the giant toad, Bufo marinus. Chem. Pharm. Bull. 1997, 45, 249-254. [CrossRef]

52. Akizawa, T.; Mukai, T.; Matsukawa, M.; Yoshioka, M.; Morris, J.F.; Butler, V.P., Jr. Structures of novel bufadienolides in the eggs of a toad, Bufo marinus. Chem. Pharm. Bull. 1994, 42, 754-756. [CrossRef]

53. Moreno, L.; Banuls, Y.; Urban, E.; Gelbcke, M.; Dufrasne, F.; Kopp, B.; Kiss, R.; Zehl, M. Structure-activity relationship analysis of bufadienolide-induced in vitro growth inhibitory effects on mouse and human cancer cells. J. Nat. Prod. 2013, 76, 1078-1084. [CrossRef]

54. Perera Córdova, W.H.; Leitão, S.G.; Cunha-Filho, G.; Bosch, R.A.; Alonso, I.P.; Pereda-Miranda, R.; Gervou, R.; Touza, N.A.; Quintas, L.E.M.; Noël, F. Bufadienolides from parotoid gland secretions of Cuban toad Peltophryne fustiger (Bufonidae): Inhibition of human kidney $\mathrm{Na}^{+} / \mathrm{K}^{+}$-ATPase activity. Toxicon 2016, 110, 27-34. [CrossRef]

55. Kwan, T.; Paiusco, A.D.; Kohl, L. Digitalis toxicity caused by toad venom. Chest 1992, 102, 949-950. [CrossRef]

56. Su, C.L.; Lin, T.Y.; Lin, C.N.; Won, S.J. Involvement of caspases and apoptosis-inducing factor in bufotalin-induced apoptosis of hep 3B cells. J. Agric. Food Chem. 2009, 57, 55-61. [CrossRef] [PubMed]

57. Zhang, D.M.; Liu, J.S.; Tang, M.K.; Yiu, A.; Cao, H.H.; Jiang, L.; Yuet-Wa Chan, J.; Tian, H.Y.; Fung, K.P.; Ye, W.C. Bufotalin from Venenum Bufonis inhibits growth of multidrug resistant HepG2 cells through G2/M cell cycle arrest and apoptosis. Eur. J. Pharmacol. 2012, 692, 19-28. [CrossRef]

58. Shimada, K.; Ro, J.S.; Ohishi, K.; Nambara, T. Isolation and characterization of cinobufagin 3-glutaroylL-arginine ester from Bufo bufo gargarizans Cantor. Chem. Pharm. Bull. 1985, 33, 2767-2771. [CrossRef]

59. Matsukawa, M.; Akizawa, T.; Morris, J.F.; Butler, V.P., Jr.; Yoshioka, M. Marinoic acid, a novel bufadienoliderelated substance in the skin of the giant toad, Bufo marinus. Chem. Pharm. Bull. 1996, 44, 255-257. [CrossRef] 
60. Bayazit, V. Biological activities of nanomaterials (bufadienolides, peptides and alkoloids) in the skin of amphibian on Gammarus pulex L. Dig. J. Nanomater. Biostructures 2010, 5, 347-354.

61. Marshall, I.G. The effects of some hemicholinium-like substances on the chick biventer cervicis muscle preparation. Eur. J. Pharmacol. 1969, 8, 204-214. [CrossRef]

62. Haimann, C.; Torri-Tarelli, F.; Fesce, R.; Ceccarelli, B. Measurement of quantal secretion induced by ouabain and its correlation with depletion of synaptic vesicles. J. Cell Biol. 1985, 101, 1953-1965. [CrossRef] [PubMed]

63. Wislicki, L.; Rosenblum, I. Effects of propranolol on the action of neuromuscular blocking drugs. Br. J. Anaesth. 1967, 39, 939-942. [CrossRef]

64. Whittaker, M.; Wicks, R.J.; Britten, J.J. Studies on the inhibition by propranolol of some human erythrocyte membrane enzymes and plasma cholinesterase. Clin. Chim. Acta 1982, 119, 107-114. [CrossRef]

65. Song, T.; Chu, X.; Zhang, X.; tao Song, Q.; Zhang, Y.; Zhang, Y.; Han, X.; Zhang, J.; Chu, L. Bufalin, a bufadienolide steroid from the parotoid glands of the Chinese toad inhibits L-type $\mathrm{Ca}^{2+}$ channels and contractility in rat ventricular myocytes. Int. J. Lab. Hematol. 2017, 31, 340-346. [CrossRef]

66. Patten, B.M.; Oliver, K.L.; Engel, W.K. Serotonin-induced muscle weakness. Arch. Neurol. 1974, 31, $347-349$. [CrossRef] [PubMed]

67. Meltzer, H.Y. Skeletal muscle necrosis following membrane-active drugs plus serotonin. J. Neurol. Sci. 1976, 28, 41-56. [CrossRef]

68. Wu, Z.S.; Cheng, H.; Jiang, Y.; Melcher, K.; Xu, H.E. Ion channels gated by acetylcholine and serotonin: Structures, biology, and drug discovery. Acta Pharmacol. Sin. 2015, 36, 895-907. [CrossRef] [PubMed]

69. Jonsson, M.; Gurley, D.; Dabrowski, M.; Larsson, O.; Johnson, E.C.; Eriksson, L.I. Distinct pharmacologic properties of neuromuscular blocking agents on human neuronal nicotinic acetylcholine receptors: A possible explanation for the train-of-four fade. Anesthesiology 2006, 105, 521-533. [CrossRef] [PubMed]

70. Haerter, F.; Eikermann, M. Reversing neuromuscular blockade: Inhibitors of the acetylcholinesterase versus the encapsulating agents sugammadex and calabadion. Expert Opin. Pharmacother. 2016, 17, 819-833. [CrossRef] [PubMed]

71. Krivoi, I.I.; Drabkina, T.M.; Kravtsova, V.V.; Vasiliev, A.N.; Eaton, M.J.; Skatchkov, S.N.; Mandel, F. On the functional interaction between nicotinic acetylcholine receptor and $\mathrm{Na}^{+}, \mathrm{K}^{+}$-ATPase. Pflugers Arch. Eur. J. Physiol. 2006, 452, 756-765. [CrossRef] [PubMed]

72. Anadón, A.; Martínez-Larrañaga, M.R.; Valerio, L.G. Onchidal and fasciculins. In Handbook of Toxicology of Chemical Warfare Agents, 2nd ed.; Gupta, R.C., Ed.; Academic Press: New York, NY, USA, 2015; pp. 411-420. [CrossRef]

73. Dal Belo, C.A.; Lucho, A.P.B.; Vinadé, L.; Rocha, L.; Seibert França, H.; Marangoni, S.; Rodrigues-Simioni, L. In vitro antiophidian mechanisms of Hypericum brasiliense Choisy standardized extract: Quercetin-dependent neuroprotection. BioMed Res. Int. 2013, 2013, 943520. [CrossRef]

74. Akaike, A.; Takada-Takatori, Y.; Kume, T.; Izumi, Y. Mechanisms of neuroprotective effects of nicotine and acetylcholinesterase inhibitors: Role of $\alpha 4$ and $\alpha 7$ receptors in neuroprotection. J. Mol. Neurosci. 2010, 40, 211-216. [CrossRef]

75. Bahuguna, A.; Khan, I.; Bajpai, V.K.; Kang, S.C. MTT assay to evaluate the cytotoxic potential of a drug. Bangladesh J. Pharmacol. 2017, 12, 115-118. [CrossRef]

76. Dvela, M.; Rosen, H.; Ben-Ami, H.C.; Lichtstein, D. Endogenous ouabain regulates cell viability. Am. J. Physiol. Cell Physiol. 2012, 302, C442-C452. [CrossRef]

77. Takada-Takatori, Y.; Kume, T.; Sugimoto, M.; Katsuki, H.; Sugimoto, H.; Akaike, A. Acetylcholinesterase inhibitors used in treatment of Alzheimer's disease prevent glutamate neurotoxicity via nicotinic acetylcholine receptors and phosphatidylinositol 3-kinase cascade. Neuropharmacology 2006, 51, 474-486. [CrossRef] [PubMed]

78. Dvir, H.; Silman, I.; Harel, M.; Rosenberry, T.L.; Sussman, J.L. Acetylcholinesterase: From 3D structure to function. Chem. Biol. Interact. 2020, 187, 10-22. [CrossRef]

79. Greenblatt, H.M.; Silman, I.; Sussman, J.L. Structural studies on vertebrate and invertebrate acetylcholinesterases and their complexes with functional ligands. Drug Dev. Res. 2000, 50, 573-583. [CrossRef]

80. Kerkhoff, J.; Noronha, J.C.; Bonfilio, R.; Sinhorin, A.P.; Rodrigues, D.J.; Chaves, M.H.; Vieira, G.M. Quantification of bufadienolides in the poisons of Rhinella marina and Rhaebo guttatus by HPLC-UV. Toxicon 2016, 119, 311-318. [CrossRef] [PubMed] 
81. Babula, P.; Masarik, M.; Adam, V.; Provaznik, I.; Kizek, R. Na ${ }^{+} / \mathrm{K}^{+}$-ATPase and cardiac glycosides to cytotoxicity and cancer treatment. Anticancer Agents Med. Chem. 2013, 13, 1069-1087. [CrossRef]

82. Hernandez-Oliveira, S.; Rostelato-Ferreira, S.; Rocha-e-Silva, T.A.A.; Randazzo-Moura, P.; Dal-Belo, C.A.; Sanchez, E.F.; Borja-Oliveira, C.R.; Rodrigues-Simioni, L. Beneficial effect of crotamine in the treatment of myasthenic rats. Muscle Nerve 2013, 47, 591-593. [CrossRef] [PubMed]

83. Vargas, L.S.; Lara, M.V.; Gonçalves, R.; Mandredini, V.; Ponce-Soto, L.A.; Marangoni, S.; Dal Belo, C.A.; Mello-Carpes, P.B. The intrahippocampal infusion of crotamine from Crotalus durissus terrificus venom enhances memory persistence in rats. Toxicon 2014, 85, 52-58. [CrossRef]

84. Rostelato-Ferreira, S.; Dal Belo, C.A.; Leite, G.B.; Hyslop, S.; Rodrigues-Simioni, L. Presynaptic neuromuscular action of a methanolic extract from the venom of Rhinella schneideri toad. J. Venom. Anim. Toxins Incl. Trop. Dis. 2014, 20, 30. [CrossRef]

85. Shibao, P.Y.T.T.; Anjolette, F.A.P.P.; Lopes, N.P.; Arantes, E.C. First serine protease inhibitor isolated from Rhinella schneideri poison. J. Venom. Anim. Toxins Incl. Trop. Dis. 2015, 21, 30. [CrossRef] [PubMed]

86. Schagger, H.; Von Jagow, G. Tricine-sodium dodecyl sulfate-polyacrylamide gel electrophoresis for the separation of proteins in the range from 1 to $100 \mathrm{kDa}$. Anal. Biochem. 1987, 166, 368-379. [CrossRef]

87. Kavran, J.M.; Leahy, D.J. Laboratory Methods in Enzymology: Protein Part C. In Methods in Enzymology; Lorsch, J., Ed.; Academic Press: New York, NY, USA, 2014; pp. 169-176. [CrossRef]

88. Vinadé, L.; Rodnight, R. The dephosphorylation of glial fibrillary acidic protein (GFAP) in the immature rat hippocampus is catalyzed mainly by a type 1 protein phosphatase. Brain Res. 1996, 732, 195-200. [CrossRef]

89. Ginsborg, B.L.; Warriner, J. The isolated chick biventer cervicis nerve-muscle preparation. Br. J. Pharmacol. 1960, 15, 410-411. [CrossRef] [PubMed]

90. Rostelato-Ferreira, S.; Dal Belo, C.A.; Silva Junior, P.I.; Hyslop, S.; Rodrigues-Simioni, L.; Rocha-e-Silva, T.A.A. Presynaptic activity of an isolated fraction from Rhinella schneideri poison. Adv. Pharm. Bull. 2018, 8, 517-522. [CrossRef]

91. Ellman, G.L.; Courtney, K.D.; Andres, V.J.; Featherstone, R.M. A new and rapid colorimetric determination of acetylcholinesterase activity. Biochem. Pharmacol. 1961, 7, 88-95. [CrossRef]

92. Bradford, M.M. A rapid and sensitive method for the quantitation of microgram quantities of protein utilizing the principle of protein-dye binding. Anal. Biochem. 1976, 72, 248-254. [CrossRef] 